\title{
Tracing changes in mantle and crustal influences in individual cone-building stages at Mt. Shasta using U-Th and Sr isotopes
}

\author{
Allison M. Wende ${ }^{a}$, Clark M. Johnson $^{a} *$ Brian L. Beard $^{a}$ \\ ${ }^{a}$ Department of Geoscience, University of Wisconsin-Madison, 1215 W Dayton Street, Madison WI \\ 53706, USA. \\ *Corresponding author. Phone: 608-262-1710; fax: 608-262-0693; email: clarkj@geology.wisc.edu.
}

\begin{abstract}
${ }^{230} \mathrm{Th}$-excess is rare in most arc lavas, but common in the Cascades, yet the origin of such excesses remains unclear. At Mt. Shasta, age-corrected $\left({ }^{230} \mathrm{Th} /{ }^{232} \mathrm{Th}\right)$ and $\left({ }^{238} \mathrm{U} /{ }^{232} \mathrm{Th}\right)$ activity ratios range from $1.108-1.290$ and $0.987-1.309\left(27.3 \%{ }^{230}\right.$ Th-excess to $6.1 \%{ }^{238} \mathrm{U}$-excess), respectively. Although small degrees of zircon crystallization $(<0.3 \%)$ may yield high $\left({ }^{230} \mathrm{Th} /{ }^{238} \mathrm{U}\right)_{0}$ in derivative magmas, high $\mathrm{Zr}$ contents, the lack of zircon as a liquidus phase, and low Th/U ratios in Mt. Shasta lavas argue against zircon fractionation. Instead, melting models suggest ${ }^{230} \mathrm{Th}$-excesses are imparted on lavas through mixing mantle-derived magmas with partial melts of a mafic amphibolite lower crust where garnet was produced in the residuum through amphibole and plagioclase destabilization. The hot nature of Cascade magmas suggest that high intrusion temperatures promoted dehydration melting in the deep crust.
\end{abstract}

At Mt. Shasta, the destruction of the ancestral cone (Sand Flat) was followed by four conebuilding stages, three of which lie in the age range of U-series geochronology. Lavas within individual eruptive stages have relatively constant $\left({ }^{230} \mathrm{Th} /{ }^{232} \mathrm{Th}\right)_{0}$ that are interpreted to reflect specific mixtures of mantle $(m)$ and lower crustal $(I c)$ melts that are characteristic of a specific stage $\left(M_{m: l c}\right)$. High $\left({ }^{230} \mathrm{Th} /{ }^{232} \mathrm{Th}\right)_{0}$ ratios identify higher proportions of lower crust in the Misery Hill stage $\left(M_{m: l c}=\sim 85: 15\right)$, whereas low $\left({ }^{230} \mathrm{Th} /{ }^{232} \mathrm{Th}\right)_{0}$ ratios reflect the more mantle-like composition of the Shastina lavas $\left(M_{m: l c}=\right.$ 95:5); in the case of Shastina lavas, very low ${ }^{87} \mathrm{Sr} /{ }^{86} \mathrm{Sr}$ ratios, down to 0.7029 , support a substantial 
mantle contribution. Changes in $\left({ }^{230} \mathrm{Th} /{ }^{232} \mathrm{Th}\right)_{0}$ ratios correlate with eruptive volume, where the most voluminous stage (Misery Hill) is inferred to have the largest proportion of crustal melt and highest $\left({ }^{230} \mathrm{Th} /{ }^{232} \mathrm{Th}\right)_{0}$ ratios. Variable $\left({ }^{230} \mathrm{Th} /{ }^{238} \mathrm{U}\right)_{0}$ ratios within, and between, eruptive groups likely reflect a combination of residence time in the lower crust and differential assimilation of bulk, non-garnetbearing crust that had $\left({ }^{230} \mathrm{Th} /{ }^{238} \mathrm{U}\right)=1$. The volume- $\left({ }^{230} \mathrm{Th} /{ }^{232} \mathrm{Th}\right)_{0}$ relations are accompanied by correlations with ${ }^{87} \mathrm{Sr} /{ }^{86} \mathrm{Sr}$ ratios, where the most radiogenic $\mathrm{Sr}$ is associated with the largest eruptive volumes, indicating that the largest magmatic episodes produced the largest amount of lower crustal interaction.

The new U-Th and Sr isotope measurements of this study, along with U-series data for other Cascade centers suggests that interaction with the lower crust exerts greater control on Cascade magma chemistry than previously recognized. Indeed, the relatively dry nature of the Cascades may offer a unique opportunity to better understand the influence of the deep crust in young continental arcs, as larger subduction components in other settings may overprint any lower crustal signature and produce lavas with large ${ }^{238} \mathrm{U}$-excesses.

Keywords: Mt. Shasta; Cascade Arc; uranium-series isotopes; strontium isotopes; crustal interaction; lower crust

\section{Introduction}

Magma generation and evolution in continental arc settings is commonly explained in terms of

3 flux-melting in the mantle wedge and differentiation processes in the upper crust. Interactions between

4 mantle-derived melts and deep continental crust may also modify the chemical and volatile

5 compositions of magmas (Hildreth and Moorbath, 1988; Conrey et al., 2001; Annen et al., 2006; Reubi et

6 al., 2011; Ankney et al., 2013). Mineral phases observed in erupted lavas may not reflect deep crustal 
7 differentiation, and "cryptic" fractionation of amphibole and garnet in the lower crust has been invoked

8 to explain the compositions of many arc magmas (e.g., Davidson et al., 2007; Hildago and Rooney, 2010;

9 Lee et al., 2006). Importantly identifying minerals involved in deep crustal magma evolution provide

10 constraints on compositional and thermal characteristics of the lower crust during melting. At upper

11 mantle and lower crustal pressures, amphibole is a near-liquidus phase in mafic arc magmas at $\mathrm{H}_{2} \mathrm{O}>5$

12 wt. $\%$ and temperatures $<1100{ }^{\circ} \mathrm{C}$. At higher temperatures and lower water contents, plagioclase is the

13 near-liquidus phase. In basaltic to andesitic magmas, plagioclase stability is suppressed and, instead,

14 garnet is a near-liquidus phase at $\mathrm{H}_{2} \mathrm{O}>5 \mathrm{wt}$. $\%$ and temperatures $850-1100{ }^{\circ} \mathrm{C}$ (e.g., Mercer and

15 Johnston, 2008; Müntener et al., 2001).

16 Unambiguous evidence for deep crustal melting and assimilation has been generally limited to

17 settings where chemical and isotopic contrasts between mantle-derived melts and crust are high (e.g.,

18 Hildreth and Moorbath, 1988). Where the deep crust is dominated by young mafic igneous rocks,

19 however, crustal interaction is more difficult to trace with commonly used isotope systems such as e.g.,

$20 \mathrm{Sr}, \mathrm{Nd}, \mathrm{Pb}, \mathrm{Hf}$, and O (e.g. Bacon et al., 1994; 1997; Hildreth 2007; Schmidt et al., 2008). Moreover,

21 crustal interaction may produce a chemical fingerprint that is difficult to distinguish from that of a

22 subduction component (e.g. Ankney et al., 2013).

Uranium-series isotopes offer a sensitive approach to discriminating between slab dehydration,

24 mantle melting, and upper and lower crustal interaction (e.g. Bourdon et al., 2000; Turner et al., 1997;

25 Zellmer et al., 2000; Berlo et al., 2004; Charlier et al., 2005; Yokoyama et al., 2006; Price et al., 2010).

26 The majority of lavas erupted from active oceanic and continental arcs have ${ }^{238} \mathrm{U}$-excesses, interpreted

27 to reflect metasomatism of the mantle wedge by U-rich slab fluids (Turner et al., 2003). Significant ${ }^{230}$ Th-

28 excesses, however, are measured in some continental arc lavas, and are instead ascribed to a variety of 
29 magmatic differentiation processes, including accessory mineral crystallization in the upper crust (e.g., Reagan et al., 2003) and assimilation of lower crustal melts of garnet-bearing or garnet-free protoliths (e.g., Ankney et al., 2013; Jicha et al., 2009).

The Cascades are commonly characterized as a "hot arc" based on the slow subduction of the relatively young Juan de Fuca and Gorda plates (Harry and Green, 1999; Wilson, 1988). High melting temperatures for primitive lavas are expected to promote extensive melting and assimilation of lower crust (e.g., Conrey et al., 2001; Elkins-Tanton et al., 2001). In contrast, previous work at Mt. Shasta argues against crustal interaction and, instead, ascribes chemical and isotopic variations in the more evolved stratocone lavas to a combination of variable slab contributions and magma mixing (Grove et al., 2005). In this study, we integrate the large chemical and isotopic database of the Mt. Shasta volcanic field with new U-Th and Sr isotope measurements to investigate potential mechanisms of ${ }^{230} \mathrm{Th}$ enrichment, and to better constrain the influence of crustal interaction in magma generation and evolution of the stratocone andesites and dacites at Mt. Shasta. Combined, these data suggest extensive crustal interaction in both lower crustal and upper crustal regions, the magnitude of which correlates with eruptive volume.

\section{Geologic Setting}

Mt. Shasta is the largest stratovolcano in the Cascades (e.g., Calvert and Christiansen, 2011). The present-day edifice has been constructed by at least four major cone-building events (Figure 1).

Basement rocks include the Paleozoic Trinity Ophiolite, as well as the Paleozoic and Mesozoic arc complexes of the Klamath mountains (Brouxel and Lapierre, 1988; Brouxel et al., 1988; Stanely et al., 1990). Following the destruction of the ancestral cone (Sand Flat, $700-400 \mathrm{ka}$ ) in one of the largest known debris avalanches ( $45 \mathrm{~km}^{3}$; Crandell, 1989), early volcanism at Mt. Shasta began about $2 \mathrm{~km}$ 
51 south of the present-day summit. Active from 300-125 ka, the Sargents Ridge cone has an estimated

52 eruptive volume of $85 \mathrm{~km}^{3}$. Initiation of the Misery Hill eruptive phase $\left(60 \mathrm{~km}^{3}\right)$ is marked by $114 \mathrm{ka}$

53 lavas exposed on the eastern flank of the edifice, but is largely identified by units of 60 to 11 ka age

54 erupted from a vent $\sim 300 \mathrm{~m}$ south of the summit. A portion of the Misery Hill cone was destroyed by

55 the plinian eruption of the Red Banks pumice at $\sim 11 \mathrm{ka}$, followed immediately by a westward shift in

56 volcanism to a satellite vent. Based on geochronology and restricted secular variation in paleomagnetic

57 data (D. Champion and R. Christiansen, unpublished data), the large satellite Shastina cone (20-30 $\mathrm{km}^{3}$ )

58 is likely to have formed over several hundred years. Volcanism retreated east in the fourth cone-building

59 stage, Hotlum, producing $\sim 49 \mathrm{~km}^{3}$ of lavas and domes of $10.4 \mathrm{ka}$ age and younger.The total eruptive

60 volume at Mt. Shasta is estimated to be $500 \mathrm{~km}^{3}$ over the last $300 \mathrm{kyr}$.

Volcanism at Mt. Shasta is characterized by brief periods of intense activity during which lavas

62 and pyroclastic flows were erupted, followed by apparent intervals of repose. Two-pyroxene andesites

63 (60-63 wt. \% $\left.\mathrm{SiO}_{2}\right)$ constitute nearly $90 \%$ of the eruptive products. Basalts $\left(<52 \mathrm{wt}\right.$. $\left.\% \mathrm{SiO}_{2}\right)$ and basaltic

64 andesites (52-54 wt. \% $\left.\mathrm{SiO}_{2}\right)$ were dominantly erupted from flank ( $<2000$ m elevation) and regional

65 vents, whereas dacites $\left(63-66 \mathrm{wt} . \% \mathrm{SiO}_{2}\right)$ were emplaced as flows and domes and are more

66 concentrated near the summit. Many andesites and dacites have low FeO/MgO ratios and, therefore,

67 may have unusually high $\mathrm{Mg \# s}\left(55-65\right.$; where $\mathrm{Mg \#}=100 * \mathrm{Mg} /(\mathrm{Mg}+\mathrm{Fe})$ ) at high $\mathrm{SiO}_{2}$ (see Figure $\left.\mathrm{A} .1 \mathrm{~B}, \mathrm{C}\right)$,

68 although Fe/Mg ratios may vary in evolved rocks. Each eruptive phase produced a wide range of large-

69 ion-lithophile element contents (e.g. Sr and Ba), and similar variability is measured for other

70 incompatible elements, including $\mathrm{U}, \mathrm{Th}$, and $\mathrm{Rb}$ (see Figure A.2). Rare earth element abundances (REE)

71 in the stratocone andesites and dacites are characterized by light REE (LREE) enrichments accompanied

72 by heavy REE (HREE) depletions (see Figure A.3). 
Interpretations of previously published major- and trace-element contents, as well as volatile

74 and isotopic compositions vary at Mt. Shasta. Some studies argue for a large subduction component and

75 limited crustal interaction (e.g. Grove et al., 2002; 2005), whereas others infer extensive assimilation of

76 crust (e.g. Streck et al., 2007). High pre-eruptive $\mathrm{H}_{2} \mathrm{O}$ contents (4-6 wt. \%) are inferred for primitive

77 basaltic andesite (BA) and primitive magnesian andesite (PMA) lavas based on phase relations,

78 experimental petrology, and olivine-hosted melt inclusions (Grove et al., 2002; Le Voyer et al., 2010;

79 Ruscitto et al., 2011). Similarly high volatile contents are inferred for intermediate-composition lavas

80 erupted from the main cone of Mt. Shasta (Grove et al., 2005; 2003). Significant upper crustal

81 assimilation in these stratocone lavas has been dismissed based on low $\mathrm{FeO} / \mathrm{MgO}$ ratios at high $\mathrm{SiO}_{2}$ (see

82 Figure A.1, Grove et al., 2005). The range of Li, B, Sr, Nd, and Pb isotope compositions has been taken to

83 be consistent with subduction processes, including subducted sediment, slab-fluid addition, or residue

84 from fluid-fluxing in the mantle wedge (Grove et al., 2002; Le Voyer et al., 2010; Magna et al., 2006;

85 Rose et al., 2001; Ruscitto et al., 2011).

In contrast, Streck et al. (2007) assert that the complex phenocryst assemblage of regional PMA

87 lavas near Mt. Shasta indicates contributions from dacitic, basaltic, and ultramafic components,

88 including those obtained from assimilated continental crust. These authors argue that the high $\mathrm{Sr}$

89 contents and high $\mathrm{Sr} / \mathrm{Y}$ ratios (Figure A.2E, F) cannot be produced by fractional crystallization of

90 primitive mafic magmas that have relatively low $\mathrm{Sr}, \mathrm{Sr} / \mathrm{Y}$, and abundant plagioclase as a liquidus phase,

91 and instead require a lower crustal contribution that may have involved melting of amphibole-bearing

92 crust and destabilization of plagioclase, releasing Sr into the melt. This scenario has been proposed

93 elsewhere in the Cascades (Ankney et al. 2013; Conrey et al., 2001), and for other arcs (Ducea and

94 Saleeby, 1998; Garrison and Davidson, 2003). 


\section{Results}

We first report below the ${ }^{238} \mathrm{U}-{ }^{230} \mathrm{Th}$ results from 29 stratocone and regional lavas from the Mt. Shasta region, followed by new Sr isotope data, with comparison to results from previous studies. Details on sample selection and analytical methods are given in Appendix B (supplemental material).

\subsection{U-Th isotopes}

The regional and stratocone lavas from Mt. Shasta have variable U-Th isotope compositions but fall within the range of those reported for other Cascade lavas (Figure 2, Bennett et al., 1982; Trimble et al., 1984; Newman et al., 1986; Volpe and Hammond, 1991; Cooper and Reid, 2003; Reagan et al., 2003; Berlo et al., 2004; Dosseto et al., 2008; Jicha et al., 2009; Ankney et al., 2013.). Using ${ }^{40} \mathrm{Ar} /{ }^{39} \mathrm{Ar}$, ${ }^{14} \mathrm{C}$, or stratigraphically estimated ages of lavas (A. Calvert and R. Christiansen, unpublished data), activity ratios of $\left({ }^{230} \mathrm{Th} /{ }^{232} \mathrm{Th}\right)$ were corrected for ${ }^{230} \mathrm{Th}$-ingrowth since the time of eruption. We note that ages of older samples (> $60 \mathrm{ka})$, and therefore the $\left({ }^{230} \mathrm{Th} /{ }^{232} \mathrm{Th}\right)_{0}$ of these lavas, are comparatively poorly constrained. As noted below, our major conclusions will be drawn from the compositions of younger rocks that have minimal uncertainties in initial Th isotope compositions.

The majority of lavas measured in this study have $\left({ }^{238} \mathrm{U} /{ }^{230} \mathrm{Th}\right)_{0}<1$, indicating ${ }^{230} \mathrm{Th}$-excess, although small ${ }^{238} \mathrm{U}$-excesses (i.e. $\left({ }^{238} \mathrm{U} /{ }^{230} \mathrm{Th}\right)_{0}>1$ ) were measured in nine lavas (Figure $2 \mathrm{~b}$ ). ${ }^{238} \mathrm{U}-{ }^{230} \mathrm{Th}$ isotope compositions are independent of rock type. Two basaltic andesites (09SH1285 and 09SH1286) have relatively high ${ }^{230} \mathrm{Th}$-excesses ( 12.3 and $27.3 \%$ respectively), whereas a small ${ }^{238} \mathrm{U}$-excess is measured in the remaining basaltic andesite (09SH1328, 1.7\%). Andesites and dacites are similarly variable in $\left({ }^{230} \mathrm{Th} /{ }^{238} \mathrm{U}\right)_{0}$ composition; the highest ${ }^{230} \mathrm{Th}$ - and ${ }^{238} \mathrm{U}$-excesses of the stratocone lavas, for example, are measured in andesites $\left(20.0 \%{ }^{230} \mathrm{Th}\right.$-excess in $07 \mathrm{SH} 1255$ and $6.1 \%{ }^{238} \mathrm{U}$-excess in 09SHC42). 
Variable ${ }^{230} \mathrm{Th}-{ }^{238} \mathrm{U}$ compositions are also found for eruptive units within specific cone-building

117 stages. Most of the Misery Hill and Shastina lavas have $\left({ }^{238} \mathrm{U} /{ }^{230} \mathrm{Th}\right)_{0}<1$, ranging from $0.61-17.9 \%$ and

$118 \quad 7.9-20.0 \%{ }^{230} \mathrm{Th}$-excess, respectively. Small ${ }^{238} \mathrm{U}$-excesses are measured in two Misery Hill lavas (0.4-

$1192.1 \%$ ) and one Shastina andesite (0.9\%). Hotlum lavas have the lowest overall ${ }^{230} \mathrm{Th}$-excesses (up to

$1205.1 \%)$ and, instead, the majority of lavas have $\left({ }^{238} \mathrm{U} /{ }^{230} \mathrm{Th}\right)_{0}>1 ;{ }^{238} \mathrm{U}$-excesses up to $6.1 \%$ are measured,

121 although most lavas have $<3 \%{ }^{238} \mathrm{U}$-excess. Within both the Misery Hill and Shastina cone-building

122 stages, lavas have relatively constant $\left({ }^{230} \mathrm{Th} /{ }^{232} \mathrm{Th}\right)_{0}$ ratios $(1.22-1.26$ and $1.16-1.18$, respectively), with

123 the exception of two lavas, 07SH1249 (Misery Hill, 1.185) and 07SH1255 (Shastina, 1.262). Hotlum lavas

124 are more variable with respect to $\left({ }^{230} \mathrm{Th} /{ }^{232} \mathrm{Th}\right)_{0}$ ratios $(1.17-1.23)$, and increasing $\left({ }^{230} \mathrm{Th} /{ }^{232} \mathrm{Th}\right)_{0}$ is

125 correlated with increasing $\left({ }^{238} \mathrm{U} /{ }^{232} \mathrm{Th}\right)$.

\subsection{Sr Isotopes}

Strontium isotope compositions for the Mt. Shasta lavas analyzed in this study vary from

0.7029-0.7038 (Figure 3), spanning a range comparable to that reported for other Shasta area lavas

129 (0.7029-0.7043; Grove et al., 2002; Zeichert, 2004) and the Cascades (0.7028-0.7043; Bullen and

130 Clynne, 1990; Leeman et al., 1990; Bacon et al., 1997; Borg et al., 1997; Jicha et al., 2009b). Measured

$131{ }^{87} \mathrm{Sr} /{ }^{86} \mathrm{Sr}$ ratios are equal to the initial ratios within analytical error. Strontium isotope compositions do

132 not vary systematically with $\mathrm{SiO}_{2}$ content (basaltic andesites, 0.7032-0.7038; andesites, 0.7031-0.7038;

133 dacites, $0.7029-0.7038)$. Although similarly broad ranges of ${ }^{87} \mathrm{Sr} /{ }^{86} \mathrm{Sr}$ ratios are reported for both Mt.

134 Adams and Lassen Peak (Bullen and Clynne 1990; Bacon et al., 1997; Borg et al., 1997; Jicha et al.,

135 2009b), this variability is primarily associated with basalts and basaltic andesites, and evolved lavas are

136 increasingly restricted to more radiogenic compositions at these volcanoes. At Mt. Shasta, however,

137 andesites and dacites extend toward lower ${ }^{87} \mathrm{Sr} /{ }^{86} \mathrm{Sr}$ ratios than those from other Cascade centers. 
139 Shastina samples have the least radiogenic $\mathrm{Sr}$ isotope compositions $\left({ }^{87} \mathrm{Sr} /{ }^{86} \mathrm{Sr} \approx 0.7029\right)$ and have

$140 \quad{ }^{87} \mathrm{Sr} /{ }^{86} \mathrm{Sr}$ ratios that nearly overlap with Juan de Fuca and Gorda MORB (0.7023-0.7028; Hegner and

141 Tatsumoto, 1987; White et al., 1987). One Shastina lava has a considerably higher ${ }^{87} \mathrm{Sr} /{ }^{86} \mathrm{Sr}$ ratio

142 (07SH1255; Figure 3B). Notably, this andesite, which is relatively mafic for Shastina lavas, also has a high

$143 \quad\left({ }^{230} \mathrm{Th} /{ }^{232} \mathrm{Th}\right)_{0}=1.26$. The Misery Hill samples of this study have a larger range in ${ }^{87} \mathrm{Sr} /{ }^{86} \mathrm{Sr}$ ratios $(0.7033-$

144 0.7038), but may be split into two groups, those with lower ${ }^{87} \mathrm{Sr} /{ }^{86} \mathrm{Sr}(0.7033)$ and those with more

145 radiogenic compositions $\left({ }^{87} \mathrm{Sr} /{ }^{86} \mathrm{Sr} \approx 0.7037-0.7038\right)$. The Hotlum lavas have the largest range of ${ }^{87} \mathrm{Sr} /{ }^{86} \mathrm{Sr}$

146 ratios and vary continuously from 0.7029 to 0.7036 .

\section{4. Discussion}

We focus our initial discussion on the U-Th isotope compositions of the stratocone lavas to

149 explore potential mechanisms of ${ }^{230}$ Th-enrichment at Mt. Shasta, including accessory mineral

150 fractionation and crustal melting. Next, we apply non-modal batch melting and mixing models to U-

151 series and trace-element data to distinguish the relative proportions of crust and mantle components

152 between, and within, eruptive units. Finally, Sr isotopes are integrated with U-Th data to constrain the

153 isotopic compositions of mafic precursor magmas and to identify heterogeneities in the crustal column

154 beneath Mt. Shasta.

1554.1 Mechanisms for creating ${ }^{230}$ Th-excess at Mt. Shasta

4.1.1 ${ }^{230}$ Th-excess as a consequence of zircon crystallization

${ }^{230} \mathrm{Th}$-excess in continental arc lavas has been attributed to crystallization of accessory phases

158 with high partition coefficients for $U$ relative to $T h\left(D_{U}>D_{T h}\right.$; e.g., Reagan et al., 2003). Zircon has $D_{U} \gg>$ 
$159 \mathrm{D}_{\mathrm{Th}}$, therefore, small degrees of crystallization will decrease $\left({ }^{238} \mathrm{U} /{ }^{232} \mathrm{Th}\right)$ at constant $\left({ }^{230} \mathrm{Th} /{ }^{232} \mathrm{Th}\right)_{0}$ to

160 create large ${ }^{230} \mathrm{Th}$-excesses. At Mt. Shasta, fractional crystallization models indicate that subtraction of

$1610.3 \%$ by mass of zircon from a parental magma can produce the largest ${ }^{230} \mathrm{Th}$ excess observed at Shasta

162 (Figure 4; Appendix D.1). Although this may seem a small, and therefore reasonable extent of

163 crystallization, subtraction of this amount of zircon would require a parental magma that initially

164 contained $1609 \mathrm{ppm} \mathrm{Zr}$ to produce a fractionated lava that had $116 \mathrm{ppm} \mathrm{Zr}$, the average of that

165 measured for Mt. Shasta andesites. There is no evidence in any Cascade lava for parental magmas with

166 such high Zr contents (Bacon et al., 1997; Borg and Clynne, 1998; Bruggman et al., 1999; Conrey et al.,

167 2001; Grove et al., 2002; Zeichert, 2004). Uranium and Th contents of Mt. Shasta lavas further

168 demonstrate that it is unlikely that zircon fractionation can be invoked as a mechanism for generating

169 the observed range of ${ }^{230} \mathrm{Th}$-excesses. In all eruptive units, magmas were more extensively depleted in

170 Th relative to $U$ (Figure 5), producing low Th/U ratios that are inconsistent with the distribution

171 coefficients of $U$ and Th in zircon $\left(D_{U}=100, D_{T h}=16.7\right.$, Blundy and Wood, 2003).

We next consider the possibility of zircon crystallization in concert with another accessory

173 mineral, such as apatite, to explain the unexpectedly low Th/U ratios. Unlike zircon, apatite favors Th

174 slightly more than $U\left(D_{U}=1.9, D_{T h}=2.82\right.$, Condomines, 1997), and high degrees of apatite crystallization

175 can generate low Th/U ratios. Assuming subtraction of $0.3 \%$ by mass of zircon, fractional crystallization

176 models require more than $25 \%$ apatite crystallization to replicate the measured Th/U ratios (yellow

177 model line, Figure 5; Appendix D.2). High proportions of apatite crystallization, however, negate the

$178{ }^{230}$ Th-excess produced by zircon crystallization, push the lavas into ${ }^{238} \mathrm{U}$-excess, and would produce very

179 low $\mathrm{P}_{2} \mathrm{O}_{5}$ contents. Considering all available data, the range of $\mathrm{Zr}(25-175 \mathrm{ppm})$ and $\mathrm{P}_{2} \mathrm{O}_{5}(0.10-0.41 \mathrm{wt}$.

$180 \%$ ) contents in the Mt. Shasta lavas (Grove et al., 2005; 2002; Zeichert, 2004) permit less 0.035\% zircon

181 and $1.47 \%$ apatite crystallization, assuming that all $\mathrm{Zr}$ and $\mathrm{P}_{2} \mathrm{O}_{5}$ is partitioned into zircon and apatite, 
182 respectively. At these proportions, zircon crystallization depletes $U$ contents only minimally and 183 produces less than $1 \%{ }^{230}$ Th-excess. An absence of zircon fractionation is further supported by 184 petrographic observations that failed to identify zircon in Shasta lavas (R. Christiansen, person. 185 commun.). In addition, low zircon saturation temperatures calculated for the stratocone andesites and 186 dacites (697- $747^{\circ} \mathrm{C}$; Boehnke et al., 2013), in combination with high estimated liquidus temperatures > $187800{ }^{\circ} \mathrm{C}$ for the majority of Shasta magmas (Grove et al., 2005), indicate that Shasta magmas were under188 saturated in Zr. We conclude, therefore, that the large range in Th/U ratios for Mt. Shasta samples 189 cannot be produced by accessory mineral fractionation. Such a conclusion holds for crystal fractionation 190 of accessory minerals at liquidus temperatures, or separation of magmas from a crystal-rich mush.

We instead interpret Th- $U$ variations in the stratocone lavas to, in part, reflect mixing of evolved 192 magmas with a more mafic component, as will be discussed in the following section. Petrographic 193 evidence in support of mixing includes anomalously mafic pyroxene and olivine grains in dacites, as well 194 as pyroxenes that have low Mg\# cores (65-72) which are mantled by high Mg\# rims (85-92) (Newman et 195 al., 1986; Streck et al., 2007). Fractional crystallization models and phenocryst mineral compositions 196 identify primitive PMA and BA lavas as possible mafic inputs, and suggest that derivative liquids that 197 were compositionally similar to the McKenzie Butte rhyodacite and an evolved PMA represent end198 member compositions that may be invoked in mixing models (Grove et al., 2005). measured in the intermediate-composition stratocone lavas means that a different explanation must be 202 sought. Most arc lavas are highly differentiated and have mineral assemblages that are the product of shallow, relatively late crystallization processes (Davidson et al., 2007). Here we consider minerals other 
204 than those observed in erupted lavas as a possible control on Th/U ratios, including cryptic mineral

205 fractionation in the mid-to lower-crust (e.g., Lee et al., 2006; Davidson et al., 2007; Hildago and Rooney, 206 2010). Although an uncommon eruptive product, garnet is observed where the lower crustal roots of 207 arcs are exposed. Deep garnet fractionation imparts distinct chemical signatures on magmas, including 208 HREE depletions, unusually high $\mathrm{Sr} / \mathrm{Y}$ ratios, moderate $\mathrm{Fe} / \mathrm{Mg}$ ratios, and, as a result of an affinity for $\mathrm{U}$ 209 relative to Th $\left(D_{U}=0.31 D_{T h}=0.074 ;\right.$ Rubatto and Hermann, 2007), significant ${ }^{230}$ Th-excesses may be 210 produced (Ankney et al., 2013; Hildago and Rooney, 2010; Jicha et al., 2009).

212 mantle and lower crustal pressures (0.8-1.2 GPa) and temperatures (800-1000 ${ }^{\circ} \mathrm{C}$, Alonso-Perez et al., 213 2009; Müntener et al., 2001), phase equilibria studies suggest that garnet is unlikely to be on the 214 liquidus in parental Cascade magmas (Mercer and Johnston, 2008). Dehydration melting of mafic 215 amphibolite, however, can produce garnet in the residuum at pressures (1-1.25 GPa) and temperatures $216\left(850-1000^{\circ} \mathrm{C}\right)$ appropriate for the lower crust beneath the Cascades, as demonstrated by vapor-absent 217 melting experimental studies (e.g., Rapp and Watson, 1995; Sen and Dunn, 1994; Wolf and Wyllie, 1994; 218 1993). Hornblende and plagioclase breakdown to produce garnet according to the reaction (assuming $219100 \mathrm{~g}$ of material):

(Eqn. 1) $67.47 \mathrm{hbl}+32.53$ plag $=20.0$ melt +80.0 residue $($ residue $=40.59 \mathrm{gt}+40.59 \mathrm{pyx}+7.92 \mathrm{plag}+$ $10.89 \mathrm{hbl})\left(950^{\circ} \mathrm{C}, 10 \mathrm{kbar} ;\right.$ Wolf and Wyllie, 1993)

222 Consequently, dehydration melting provides a mechanism for producing a garnet signature where 223 garnet was not initially present in the crust. Moreover, this reaction may influence the trace-element 224 compositions of magmas in equilibrium with the residue, specifically Sr enrichment due to plagioclase 225 breakdown and high LREE/HREE ratios due to residual garnet. 
Garnet and lower crustal melting processes have been found to influence magma chemistry at

227 other Cascade centers, including Crater Lake (Ankney et al., 2013), Mt. Adams (Jicha et al., 2009), and

228 Mt. Jefferson (Conrey et al., 2001). To evaluate the role of garnet in producing ${ }^{230} \mathrm{Th}$-excess at Mt.

229 Shasta, non-modal batch melting models were applied to both lower crustal and mantle sources

230 according to the methods of Ankney et al. (2013). For lower crustal melting, we selected an amphibolite

231 composition that has a modal mineralogy equivalent to the starting materials in equation 1 . A spinel

232 Iherzolite was chosen as the mantle source, using a starting composition of $51 \%$ olivine, $23 \%$

233 clinopyroxene, $21 \%$ orthopyroxene, and 5\% spinel. Multiple melting mode $(P)$ values for lower crustal

234 and mantle melts are the same as those used by Ankney et al. (2013). The melting reactions for lower

235 crustal $P$ values were determined from modal compositions in equation 1 and mantle $P$ values were

236 determined from the following equation:

237 (Eqn. 2) $10.34 s p+40.54$ en $+49.12 d i=67.23$ melt +32.77 residue (residue $=87$ fo +13 en) (Eqn. 3 ,

238 normalized to $100 \mathrm{~g}$; Ottonello et al., 1984)

239 Melting models were then applied to approximate the $U$ and Th isotope compositions of melts at

240 various mantle $\left(X_{\text {mantle }}^{\text {melt }}\right)$ and lower crustal $\left(X_{\text {lower crust }}^{\text {melt }}\right)$ melt fractions (Appendix D.3; Table A.2).

Progressive dehydration melting of amphibolite produces increasing amounts of garnet until

242 amphibole is exhausted and the residual garnet and pyroxene begin to destabilize (Eqn. 1; Wolf and

243 Wyllie, 1994; 1993). Accordingly, calculations involving non-modal batch melting models produce high

$244{ }^{230}$ Th-excesses at high percent amphibolite melt, up to $34 \%$ at $X_{\text {lower } \text { crust }}^{\text {melt }}=0.2$ (Figure 6), where large

245 quantities of garnet are produced. Garnet is not generated by melting spinel lherzolite (Eqn. 2). Batch

246 melting models, however, demonstrate that partial mantle melting may also produce melts that are

247 moderately enriched in ${ }^{230} \mathrm{Th}$, although the largest excesses are calculated for the smallest melt fractions 
$248\left(13 \%{ }^{230} \mathrm{Th}\right.$-excess at $\left.X_{\text {mantle }}^{\text {melt }}=0.01\right)$. It is important to note that the $\mathrm{U} / \mathrm{Th}$ ratios of modeled mantle 249 melts are not significantly affected by initial mantle composition, given the low partition coefficients of $250 \mathrm{U}$ and Th in ultramafic systems. For example, partial melting of a garnet lherzolite mantle creates ${ }^{230} \mathrm{Th}-$ 251 excesses only slightly higher than that produced by a spinel lherzolite composition $\left(18.2 \%{ }^{230} \mathrm{Th}\right.$-excess 252 at $X_{\text {mantle }}^{\text {melt }}=0.01$, Ankney et al., 2013).

We combine the effects of mantle and lower crustal melting at various melt fractions through 254 mixing in varying proportions to account for the range of ${ }^{238} \mathrm{U}-{ }^{230} \mathrm{Th}$ compositions measured in the Mt. 255 Shasta stratocone lavas. The extent of ${ }^{230} \mathrm{Th}$-excess at Mt. Shasta is best approximated by a mixture of 256 mantle and crustal melts at $X_{\text {mantle }}^{\text {melt }}=X_{\text {lower crust }}^{\text {melt }}=0.15$ (Figure 6), although it is important to note that 257 a variety of melt fractions for the two components can explain the range in ${ }^{230} \mathrm{Th}$-excess at Mt. Shasta. 258 Broadly, however, relatively high mantle and lower crustal melt fractions are consistent with 259 experimental data for primitive basalts (Grove et al., 2002) and expectations for extensive lower crustal 260 melting in the Cascades (Conrey et al., 2001; Elkins-Tanton et al., 2001). variable crustal melt fractions to a mantle-derived melt (Figure 6), although, in detail, a third component 264 is required. Assimilation of "old" bulk crust that lies along the equiline, in addition to young, garnet265 bearing crust, is a more likely explanation for lavas that have moderate ${ }^{230}$ Th-excesses (lie close to the 266 equiline) than very low percent $(<1 \%)$ crustal melting, given the difficulty of extracting small melt 267 fractions (e.g. Bourdon et al., 2000; Price et al., 2007; 2010). We suggest that non-garnet-bearing, mid268 to lower-crust was assimilated by lavas that plot near the equiline, but at $\left({ }^{238} \mathrm{U} /{ }^{232} \mathrm{Th}\right)$ ratios that were significantly different from those of the mantle. In this scenario, relatively constant mantle and lower 
270 crustal melt fractions mix to produce magmas represented by individual eruptive units that have similar

271 initial $\left({ }^{230} \mathrm{Th} /{ }^{232} \mathrm{Th}\right)$ and high ${ }^{230} \mathrm{Th}$-excesses. These magmas would subsequently undergo different

272 degrees of assimilation of crust that lies along the equiline during ascent, increasing their $\left({ }^{238} \mathrm{U} /{ }^{232} \mathrm{Th}\right)$

273 ratios while maintaining relatively constant $\left({ }^{230} \mathrm{Th} /{ }^{232} \mathrm{Th}\right.$ ) (Figure 6). Mixing relations between mantle

274 melts, garnet-bearing young crust (high $\left.\left({ }^{230} \mathrm{Th} /{ }^{238} \mathrm{U}\right)_{0}\right)$, and old bulk crust (equiline) with variable $\mathrm{U} / \mathrm{Th}$

275 ratios are illustrated in Figure A.4, where inversion of the U/Th ratio has been done to produce linear

276 mixing lines. The majority of Mt. Shasta lavas lie within a three component mixing triangle tied down by

277 a low $\left({ }^{232} \mathrm{Th} /{ }^{238} \mathrm{U}\right)$ bulk crustal component on the equiline, although some variability in bulk crust

$278 \quad\left({ }^{232} \mathrm{Th} /{ }^{238} \mathrm{U}\right)$ is expected.

279 Trace elements that are sensitive to garnet fractionation, such as Ce and $\mathrm{Y}$, provide a test of our 280 model that ${ }^{230}$ Th-excess reflects garnet production during dehydration melting (Figure 7; A.5; Table A.2

281 Appendix D.4). As garnet production increases with the progressive breakdown of plagioclase and

282 hornblende, lower crustal melts will be simultaneously enriched in ${ }^{230} \mathrm{Th}, \mathrm{Ce}$, but depleted in $\mathrm{Y}$ and the

283 HREEs (in garnet $D_{C e}=0.016, D_{Y}=5.27$, Qian and Hermann et al., 2013). The high $C e / Y$ ratios that

284 identify a role for garnet are consistent with the high Sr/Y and Dy/Yb ratios of the Mt. Shasta lavas

285 (Figure A.6; A.7), although $\mathrm{Sr} / \mathrm{Y}$ ratios tend to be more scattered than Ce/Y ratios due to late-stage 286 plagioclase fractionation.

Overall, high $\mathrm{Ce} / \mathrm{Y}$ ratios between, but especially within, individual eruptive units are correlated

288 with ${ }^{230} \mathrm{Th}$-excess. Most lavas, however, have a lower $\left({ }^{230} \mathrm{Th} /{ }^{238} \mathrm{U}\right)_{0}$ than that predicted by melting-mixing 289 models. This may in part reflect magma residence time, as demonstrated by the decay curves in Figure 290 7. A residence time of $100 \mathrm{kyr}$ is required to reproduce the $\left({ }^{230} \mathrm{Th} /{ }^{238} \mathrm{U}\right)_{0}$ of the Misery Hill lavas, and $291 \sim 125 \mathrm{kyr}$ is predicted for the Shastina dacites. This is contrary to the short residence time implied by the 
292 comparatively low phenocryst content of the Shastina lavas (Grove et al., 2005), as well as the rapid

293 eruption rate of the Shastina stage. As an alternative to long residence times, we suggest that

294 assimilation of bulk crust that is old enough to lie on the equiline (i.e. $\left({ }^{230} \mathrm{Th} /{ }^{238} \mathrm{U}\right)_{0}=1$ ) is responsible for

295 the more modest $\left({ }^{230} \mathrm{Th} /{ }^{238} \mathrm{U}\right)_{0}$ of the lavas with respect to $\mathrm{Ce} / \mathrm{Y}$. This model implies a greater bulk crustal

296 (equiline) influence in the Misery Hill and Hotlum units, whereas Shastina lavas would contain a smaller

297 bulk crustal (equiline) component. Petrographic evidence in support of assimilation includes granitic,

298 metasedimentary, and peridotite (assumed to be derived from the Trinity Ophiolite) xenoliths included

299 in all eruptive units (Newman et al., 1986; Grove et al. (2005).

It is important to note that, in this combined melting-mixing-assimilation model, the

$301 \quad\left({ }^{230} \mathrm{Th} /{ }^{238} \mathrm{U}\right)_{0}$ ratios calculated for the modeled mixture, and therefore the predicted fractions of bulk

302 crustal assimilation, are highly dependent on the distribution coefficients of $U$ and Th in garnet.

303 Accordingly, both the process (e.g., mixing or assimilation fractional crystallization) and extent of bulk

304 crustal assimilation cannot be robustly quantified without independent constraints (Figures 7, A.5).

305 Instead, this model demonstrates that lower $\left({ }^{230} \mathrm{Th} /{ }^{238} \mathrm{U}\right)_{0}$ ratios relative to those predicted by models of

306 garnet production during lower crustal melting likely result from a combination of variable deep crustal

307 residence times and bulk crustal assimilation.

\subsection{Constraints on the proportions of mantle and crustal component}

Although there is a wide range of $\left({ }^{238} \mathrm{U} /{ }^{232} \mathrm{Th}\right)$ ratios for individual units, the $\left({ }^{230} \mathrm{Th} /{ }^{232} \mathrm{Th}\right)_{0}$ ratios

310 of different cone-building stages are relatively constant (Figure 6). Early U-series studies of the Cascades

311 observed that young (<10 ka) lavas from the same volcano maintained constant $\left({ }^{230} \mathrm{Th} /{ }^{232} \mathrm{Th}\right)_{0}$ over a

312 range of $\left({ }^{238} \mathrm{U} /{ }^{232} \mathrm{Th}\right)$, and consequently hypothesized that the reservoirs feeding each volcano must be

313 homogeneous with respect to Th-isotope compositions (Newman et al., 1986). Our high-precision data 
314 display similar trends at Mt. Shasta over a range of ages, suggesting that Th isotope homogeneity exists

315 on the scale of individual cone-building stages. We interpret the homogeneous $\left({ }^{230} \mathrm{Th} /{ }^{232} \mathrm{Th}\right)_{0}$ of

316 individual cone-building stages, which produce distinct horizontal arrays on an equiline diagram (Figure

317 6), to correspond to distinct mixing proportions of mantle and lower crustal (high ${ }^{230} \mathrm{Th}$-excess) melts

318 that are apparently characteristic of specific cone-building stages. This in turn suggests that the nature

319 of magmatic reservoirs that were tapped by successive cone-building stages was fundamentally

320 determined in the lower crust. Below we explore mixing proportions of mantle and lower crustal melts

$321\left(M_{\text {m:lc }}\right)$ at $X_{\text {mantle }}^{\text {melt }}=X_{\text {lower }}^{\text {melt }}$ crust $=0.15$.

Overall, the Misery Hill and Shastina units have the highest and lowest proportion of lower

323 crustal melt, respectively. The higher $\left({ }^{230} \mathrm{Th} /{ }^{232} \mathrm{Th}\right)_{0}$ ratios of the Misery Hill andesites and dacites suggest

$324 M_{m: l c}=\sim 85: 15$, whereas the lower $\left({ }^{230} \mathrm{Th} /{ }^{232} \mathrm{Th}\right)_{0}$ ratios measured in the Shastina lavas imply a more

325 mantle-rich mixture of $\sim 95: 5$. Notably, some units have exceptions. The high $\left({ }^{230} \mathrm{Th} /{ }^{232} \mathrm{Th}\right)_{0}$ of one

326 Shastina andesite (07SH1255) implies a more dominant lower crustal component, close to but slightly

327 higher than that suggested for the Misery Hill lavas, whereas the youngest Misery Hill dacite measured

328 (07SH1249) has a comparatively low $\left({ }^{230} \mathrm{Th} /{ }^{232} \mathrm{Th}\right)_{0}$, indicating a more dominant mantle component,

329 similar to that interpreted for the Shastina lavas. It is difficult to evaluate if these two lavas record

330 anomalies in mantle and lower crustal melt proportions or unusual $\left({ }^{230} \mathrm{Th} /{ }^{238} \mathrm{U}\right)_{0}$ ratios in the source

331 region.

Hotlum andesites and dacites have a wider range of $\left({ }^{230} \mathrm{Th} /{ }^{232} \mathrm{Th}\right)_{0}$ compositions than those from

333 the Misery Hill or Shastina units. Samples that have high ${ }^{230} \mathrm{Th}$-excess have low $\left({ }^{230} \mathrm{Th} /{ }^{232} \mathrm{Th}\right)_{0}$, similar to

334 that measured for the Shastina dacites, but become more radiogenic as $\left({ }^{238} \mathrm{U} /{ }^{232} \mathrm{Th}\right)$ increases, to ${ }^{238} \mathrm{U}$ -

335 excesses of up to $6 \%$. Variation in the $\left({ }^{230} \mathrm{Th} /{ }^{232} \mathrm{Th}\right)_{0}$ ratios may be interpreted as a consequence of 
336 shifting mantle and lower crustal melt mixing proportions in the Hotlum parent lavas from $M_{m: l c}=\sim 95: 5$

337 to $M_{m: l c}=\sim 85: 15$. This explanation, however, fails to account for the apparent correlation of

$338 \quad\left({ }^{230} \mathrm{Th} /{ }^{232} \mathrm{Th}\right)_{0}$ with increasing $\left({ }^{238} \mathrm{U} /{ }^{232} \mathrm{Th}\right) .{ }^{238} \mathrm{U}$-excesses are rare in the Cascades, but at other Cascade

339 volcanoes that contain ${ }^{230} \mathrm{Th}$-excess, ${ }^{238} \mathrm{U}$-excess is attributed to assimilation of hydrothermally altered

340 upper crust, such as at Crater Lake (Ankney et al., 2013). Although small ${ }^{238} \mathrm{U}$-excesses are found in two

341 Misery Hill samples $(<2 \%)$, the highest ${ }^{238} \mathrm{U}$-excesses are measured in the Hotlum cone-building lavas, by

342 which time a hydrothermal system at Mt. Shasta might have been well developed. An absence of ${ }^{238} \mathrm{U}$ -

343 excess in the Shastina lavas might therefore be explained by relatively rapid transport from deep crustal

344 levels, minimizing opportunity for upper crustal assimilation.

An important observation is the positive correlation between eruptive volume and $\left({ }^{230} \mathrm{Th} /{ }^{232} \mathrm{Th}\right)_{0}$,

346 and hence proportion of lower crustal melt relative to mantle melt during mixing. The largest cone-

347 building stage, Misery Hill $\left(60 \mathrm{~km}^{3}\right)$ has the largest proportion of lower crustal melt, and we interpret

348 this to reflect a relatively large lower crustal magmatic footprint that in turn generated relatively large

349 amounts of amphibole dehydration melting. Similarly, the intermediate-volume Hotlum stage $\left(49 \mathrm{~km}^{3}\right)$

350 has intermediate $\left({ }^{230} \mathrm{Th} /{ }^{232} \mathrm{Th}\right)_{0}$ ratios, suggesting a comparatively smaller lower crustal melt component.

351 Both Misery Hill and Hotlum lavas have $\left({ }^{230} \mathrm{Th} /{ }^{238} \mathrm{U}\right)_{0}$ that extend to the equiline, indicating additional

352 crustal interaction in the absence of garnet. In contrast, the smallest volume eruptive stage, Shastina

$353\left(20-30 \mathrm{~km}^{3}\right)$, which erupted very quickly, has the lowest $\left({ }^{230} \mathrm{Th} /{ }^{232} \mathrm{Th}\right)_{0}$ ratios, suggesting the greatest

354 mantle contribution. Moreover, Shastina lavas are dominated by ${ }^{230}$ Th-excess, indicating minimal

355 interaction with non-garnet-bearing crust, in contrast to those of Hotlum and Misery Hill.

The more primitive regional lavas have the most variable $\left({ }^{230} \mathrm{Th} /{ }^{232} \mathrm{Th}\right)_{0}$ ratios measured at Mt.

357 Shasta, ranging from 1.09 to 1.26 . Like Hotlum, $\left({ }^{230} \mathrm{Th} /{ }^{232} \mathrm{Th}\right)_{0}$ ratios appear to increase with decreasing 
$358 \quad\left({ }^{230} \mathrm{Th} /{ }^{238} \mathrm{U}\right)_{0}$. This variability, however, is unlikely to be a consequence of assimilation of hydrothermally 359 altered upper crust. As noted in section 3.1, ages of these older samples (> $60 \mathrm{ka}$ ) are comparatively 360 poorly constrained, yielding larger errors for correction for ${ }^{230} \mathrm{Th}$ ingrowth or decay after eruption 361 relative to the younger cone-building stages discussed above. Consequently, we have focused 362 interpretations on the ${ }^{238} \mathrm{U}_{-}^{230} \mathrm{Th}$ compositions of only the more evolved andesites and dacites from the 363 three youngest eruptive stages.

\subsection{Sr-Th relations and injection of precursor magmas}

Strontium isotopes can be used to further constrain the proportion of mantle and lower crustal melt components, defined in section 4.3 above as $M_{m: l c}$. Although scatter is present, $\left({ }^{230} \mathrm{Th} /{ }^{232} \mathrm{Th}\right)_{0}$ is

367 positively correlated with ${ }^{87} \mathrm{Sr} /{ }^{86} \mathrm{Sr}$ ratios (Figure 8A). The low ${ }^{87} \mathrm{Sr} /{ }^{86} \mathrm{Sr}$ ratios of the Shastina andesite 368 and dacites (0.7029), and the more radiogenic compositions measured for Misery Hill lavas (up to $3690.7038)$, are consistent with interpretations that increasing $\left({ }^{230} \mathrm{Th} /{ }^{232} \mathrm{Th}\right)_{0}$ reflects a larger proportion of 370 lower crustal melt in the Misery Hill unit. The intermediate $\left({ }^{230} \mathrm{Th} /{ }^{232} \mathrm{Th}\right)_{0}$ ratios in Hotlum lavas, 371 indicating an intermediate amount of lower crustal melt relative to Shastina and Misery Hill, are 372 compatible with the more moderate ${ }^{87} \mathrm{Sr} /{ }^{86} \mathrm{Sr}$ ratios measured for this unit.

374 variation within individual eruptive units. For example, despite nearly uniform $\left({ }^{230} \mathrm{Th} /{ }^{232} \mathrm{Th}\right)_{0}$, Misery Hill 375 lavas have a range of ${ }^{87} \mathrm{Sr} /{ }^{86} \mathrm{Sr}$ ratios that is nearly half of that measured for all samples in this study. $376 \mathrm{High}{ }^{87} \mathrm{Sr} /{ }^{86} \mathrm{Sr}$ ratios distinguish Misery Hill lavas that have high ${ }^{230} \mathrm{Th}$-excess from those on or near the 377 equiline (0.7037 and 0.7033 respectively; Figure 8). Consequently, differential assimilation of bulk crust 378 might be expected to account for variable $\mathrm{Sr}$ isotope compositions. Relatively high ${ }^{87} \mathrm{Sr} /{ }^{86} \mathrm{Sr}$ ratios, 379 however, have been measured in primitive basalts (up to 0.7045; Figure 3), indicating that Sr isotope 
380 heterogeneity may also reflect variability in the mantle-derived magmas. It is conceivable then that 381 assimilation of deep, non-garnet bearing crust, responsible for decreasing $\left({ }^{230} \mathrm{Th} /{ }^{238} \mathrm{U}\right)_{0}$ within eruptive 382 groups, could also produce a decrease in ${ }^{87} \mathrm{Sr} /{ }^{86} \mathrm{Sr}$ ratios.

The same range of ${ }^{87} \mathrm{Sr} /{ }^{86} \mathrm{Sr}$ ratios is observed in samples with and without ${ }^{230} \mathrm{Th}$-excess (Figure 8B). As such, Sr isotope variability may signify partial mantle melting processes where primary magmas 385 that dominantly had low, MORB-like ${ }^{87} \mathrm{Sr} /{ }^{86} \mathrm{Sr}$ ratios (Juan de Fuca and Gorda MORB: 0.7023-0.7028, 386 Hegner and Tatsumoto, 1987; White et al., 1987) ascended through and assimilated portions of a crustal 387 column that was heterogeneous with respect to Sr isotopes. Existing data suggest a geographic control on $\mathrm{Sr}$ isotope crustal composition (Figure 9). Lavas that have low ${ }^{87} \mathrm{Sr} /{ }^{86} \mathrm{Sr}$ ratios were erupted from 389 vents in the northwest quadrant of the volcano, whereas more radiogenic compositions are measured in 390 samples from the south and east. Variable Sr isotope compositions are imparted on eruptive units that 391 sample both crustal compositions (e.g. Sargents Ridge, Misery Hill, and Hotlum). We note that this 392 geographic variability is evident in even the oldest eruptive deposits and is not strongly correlated with 393 U-Th isotope compositions. Accordingly, Sr isotope heterogeneity in the crust likely pre-dated the 394 ancestral Mt. Shasta cone (Sand Flat, 700-400 ka) and may reflect the compositions of the mid- to 395 upper-crust.

\section{Model of the Mt. Shasta magmatic system}

Figure 10 shows a schematic model of the magmatic processes consistent with the elemental and isotopic variations that may have produced the Mt. Shasta stratocone andesites and dacites. Primitive mantle melts $\left(X_{\text {mantle }}^{\text {melt }} \approx 0.15\right)$ that contain slight ${ }^{230}$ Th-excesses $(<1 \%)$ and dominantly MORB-

400 like ${ }^{87} \mathrm{Sr} /{ }^{86} \mathrm{Sr}$ ratios are envisioned to have ascended through the mantle wedge and accumulated at the 401 base of the lower crust to create a deep crustal hot zone (e.g., Annen et al., 2006). The high primary 
temperatures of mantle-derived magmas inferred to be parental to the Cascades (up to $1300{ }^{\circ} \mathrm{C}$, Elkins-

Tanton et al., 2001) should have promoted dehydration melting of an amphibolite lower crust, accompanied by amphibole and plagioclase break down to produce garnet in the residuum (equation 1), generating hydrous melts that had large ${ }^{230} \mathrm{Th}$-excesses (up to $34 \%$ ), high $\mathrm{Sr} / \mathrm{Y}$ and $\mathrm{Ce} / \mathrm{Y}$ ratios, and HREE depletions (Table A.2). These partial lower crustal melts $\left(X_{\text {lower } \text { crust }}^{\text {melt }} \approx 0.15\right)$ subsequently mixed with mantle-derived magmas in distinct proportions that, on average, created magmas that contained high

408 initial ${ }^{230} \mathrm{Th}$-excesses (14-30\%) and $\left({ }^{230} \mathrm{Th} /{ }^{232} \mathrm{Th}\right)_{0}$ ratios which are characteristic of individual eruptive 409 stages. The magmatic products of this mixing event may have been stored in the deep crust for up to $10^{5}$ 410 years (e.g. Annen et al., 2006), during which assimilation of surrounding deep non-garnet-bearing

411 (equiline) crust may have also occurred, although the U-Th isotope data do not uniquely constrain 412 magma residence time. Both ageing and bulk assimilation processes would act to decrease the initial $413{ }^{230}$ Th-excess of the magmas. Upon segregation from the lower crust, buoyant mafic magmas ascended a mid- to upper415 crustal column that is laterally heterogeneous with respect to $\mathrm{Sr}$ isotope compositions. Crust in the 416 northwest quadrant of the Mt. Shasta volcanic field has less radiogenic ${ }^{87} \mathrm{Sr} /{ }^{86} \mathrm{Sr}$ ratios $(0.7029-0.7033)$

417 than that in the south and east (0.7034-0.7043). Fractional crystallization, mixing of variably evolved 418 derivative magmas, and crustal assimilation is envisioned to have subsequently occurred over a range of 419 depths to produce stratocone lavas which have variable $\left({ }^{230} \mathrm{Th} /{ }^{238} \mathrm{U}\right)$ and ${ }^{87} \mathrm{Sr} /{ }^{86} \mathrm{Sr}$ ratios.

\section{Conclusions} Continental arc lavas are often described as the products of flux-melting in the mantle-wedge

422 and differentiation processes in the upper crust. Interactions between mantle-derived melts and deep 423 continental crust, however, may also influence the chemical and volatile compositions of magmas, 
424 although this contribution is difficult to identify where the deep crust is compositionally similar to 425 parental arc magmas. At Mt. Shasta, previous models for magma generation and evolution of the 426 stratocone lavas have dismissed significant crustal interaction, and instead attribute incompatible 427 element enrichments and isotopic variability entirely to a subduction component (Grove et al., 2005).

428 The new U-Th and Sr isotope measurements of this study, combined with the existing chemical and 429 isotopic database from the Mt. Shasta volcanic system indicate extensive interaction in both lower- and 430 upper-crustal regions.

432 the subducting slab as the sole source for many trace elements. Instead, we ascribe the large ${ }^{230} \mathrm{Th}-$

433 excesses (up to 20\%) and high $\mathrm{Ce} / \mathrm{Y}$ and $\mathrm{Sr} / \mathrm{Y}$ ratios of the stratocone andesites and dacites to

434 assimilation of partial melts from a mafic amphibolite lower crust where garnet was produced in the 435 residuum. Dehydration melting processes in the deep crust may also contribute a portion of the 436 volatiles, as sampled by olivine-hosted melt inclusions, and fluid mobile elements (Grove et al., 2003;

437 2002; Le Voyer et al., 2010; Ruscitto et al., 2011). A range of ${ }^{230}$ Th-excess within and between eruptive 438 units reflects variable residence time and variable assimilation of bulk, non-garnet-bearing crust. Distinct $439 \quad\left({ }^{230} \mathrm{Th} /{ }^{232} \mathrm{Th}\right)_{0}$ ratios are found in individual cone-building stages, indicating that magmas formed from 440 mixing variable proportions of mantle and lower crustal melts. The greatest lower crustal component is 441 found in the largest eruptive stage considered in this study, Misery Hill, presumably reflecting a large 442 magmatic footprint in the lower crust relative to that of the smaller Hotlum and Shastina stages.

443 Although it seems likely that subduction components contributed to the chemical characteristics of 444 primitive Cascade lavas, our results suggest that lower crustal interaction can produce compositions that 445 are similar to those ascribed to subduction. Our focus on the cone-building stages at Shasta indicates a 446 particularly important crustal history for these evolved magmas. Variability in ${ }^{87} \mathrm{Sr} /{ }^{86} \mathrm{Sr}-\left({ }^{230} \mathrm{Th} /{ }^{238} \mathrm{U}\right)_{0}$ 
447 relations suggests that variable Sr isotope compositions in the Mt. Shasta lavas are unlikely to be 448 exclusively inherited from magma generation processes in the mantle and may be a consequence of 449 assimilation of crust that is laterally variable in isotopic compositions.

450 If future work confirms that ${ }^{230}$ Th-excess is a characteristic feature of Cascade lavas, we suggest 451 that interaction with the lower crust has a greater effect on magma chemistry throughout the Cascades 452 than previously thought. Moreover, the comparatively dry nature of this arc may offer a unique 453 opportunity to understand the influence of the lower crust in continental arc settings. In other young 454 arcs, it is also likely that the deep crust exerts some control on magma composition, but a large 455 subduction component may mask any lower crustal signature and produce lavas with ${ }^{238} \mathrm{U}$-excess.

\section{Acknowledgements}

We thank Andrew Calvert and Robert Christiansen for providing samples and for sharing unpublished mapping and analyses, as well as their extensive knowledge of the Mt. Shasta volcanic system. We also thank Meagan Ankney for her assistance in obtaining the U-Th isotope measurements, and for many thoughtful discussions related to this project. Reviews by Erik Klemetti and an anonymous reviewer helped us to improve the quality and clarity of this manuscript. We also thank Editor Tasmin Mather for helpful editorial comments. This work was supported by National Science Foundation Grants No. 1144937 and 1028462, as well as a gift from Chevron. 


\section{References Cited}

Alonso-Perez R, Muentener O, Ulmer P (2009) Igneous garnet and amphibole fractionation in the roots of island arcs: experimental constraints on andesitic liquids. Contributions to Mineralogy and Petrology 157: 541-558.

Ankney ME, Johnson CM, Bacon CR, Beard BL, Jicha BR (2013) Distinguishing lower and upper crustal processes in magmas erupted during the buildup to the 7.7 ka climactic eruption of Mount Mazama, Crater Lake, Oregon, using U-238-Th-230 disequilibria. Contributions to Mineralogy and Petrology 166: 563-585.

Annen C, Blundy JD, Sparks RSJ (2006) The genesis of intermediate and silicic magmas in deep crustal hot zones. Journal of Petrology 47: 505-539.

Bacon CR, Bruggman PE, Christiansen RL, Clynne MA, Donnelly-Nolan JM, Hildreth W (1997) Primitive magmas at five Cascade volcanic fields: Melts from hot, heterogeneous sub-arc mantle. Canadian Mineralogist 35: 397-423.

Bacon CR, Gunn SH, Lanphere MA, Wooden JL (1994) Multiple isotopic components in Quaternary volcanic rocks of the Cascade arc near Crater Lake, Oregon. Journal of Petrology 35: 1521-1556.

Barnes CG, Petersen SW, Kistler RW, Prestvik T, Sundvoll B (1992) Tectonic implications of isotopic variation among Jurassic and Early Cretaceous plutons, Klamath Mountains. Geological Society of America Bulletin 104: 117-126.

Bennett JT, Krishnaswami S, Turekian KK, Melson WG, Hopson CA (1982) The uranium and thorium decay series nuclides in Mt. St. Helens effusives. Earth and Planetary Science Letter 60: 61-69.

Berlo K, Turner S, Blundy J, Hawkesworth C (2004) The extent of U-series disequilibria produced during partial melting of the lower crust with implications for the formation of the Mount St. Helens dacites. Contributions to Mineralogy and Petrology 148: 122-130.

Blundy JD, Wood BJ (2003) Mineral-melt partitioning of uranium, thorium, and their daughters. In Bourdon B, Henderson GM, Lundstrom CC, Turner SP (eds) Uranium-series geochemistry, vol 52. Reviews in Mineralogy and Geochemistry, pp 59-123.

Boehnke P, Watson BE, Trail D, Harrison TM, Schmitt AK (2013) Zircon saturation re-revisted. Chemical Geology 351:324-334.

Borg LE, Clynne MA, Bullen TD (1997) The variable role of slab-derived fluids in the generation of a suite of primitive calc-alkaline lavas from the southernmost Cascades, California. Canadian Mineralogist 35, 425-452.

Borg LE, Clynne MA (1998) The petrogenesis of felsic calc-alkaline magmas from the southernmost Cascades, California: Origin by partial melting of basaltic lower crust. Journal of Petrology: 39, 1197-1222.

Bourdon B, Wörner G, Zindler A (2000) U-series evidence for crustal involvment and magma residence times in the petrogenesis of Parinacota volcano, Chile. Contributions to Mineralogy and Petrology 139: 458-469.

Brouxel M, Lapierre H (1988) Geochemical study of an early Paleozoic island-arc-back-arc basin system. Part 1: the Trinity Ophiolite (northern California). Geological Society of America Bulletin 100: 1111-1119.

Brouxel M, Lapierre H, Michard A, Albarede F (1988) Geochemical study of an early Paleozoic island-arcback-arc basin system. 2. Eastern Klamath, early to middle Paleozoix island-arc volcanic rocks. Geological Society of America Bulletin: 100, 1120-1130. 
Bruggman PE, Bacon CR, Aruscavage PJ, Lerner RW, Schwarz LJ, Stewart KC (1987) Chemical analyses of rocks and glass separates from Crater Lake National Park and vicinity, Oregon. US Geological Survey Open-File Report 38:57-87.

Bullen TD, Clynne MA (1990) Trace-element and isotopic constraints on magmatic evolution at Lassen volcanic center. Journal of Geophysical Research-Solid Earth and Planets 95: 19671-19691.

Calvert AT, Christiansen RL (2011) Episodic growth of Mt. Shasta, CA, documented by argon geochronology. Fall AGU meeting. Abstract V13C-2613.

Charlier BLA, Wilson CJN, Lowenstern JB, Blake S, Van Calsteren PW, Davidson JP (2005) Magma generation at a large, hyperactive silicic volcano (Taupo, New Zeland) revealed by U-Th and U-Pb systematics in zircons. Journal of Petrology 46: 3-32.

Condomines M (1997) Dating recent volcanic rocks through ${ }^{230} \mathrm{Th}-{ }^{238} \mathrm{U}$ disequilibrium in accessory minerals: Example of the Puy de Dôme (French Massif Central). Geology 25: 375-378.

Conrey RM, Hooper PR, Larson PB, Chesley J, Ruiz J (2001) Trace element and isotopic evidence for two types of crustal melting beneath a High Cascade volcanic center, Mt. Jefferson, Oregon. Contributions to Mineralogy and Petrology 141: 710-732.

Cooper KM, Reid MR (2003) Re-examination of crystal ages in recent Mount St. Helens lavas: implications for magma reservoir processes. Earth and Planetary Science Letters 213: 149-167.

Crandell DR (1989) Gigantic debris avalanche of Pleistocene age from ancestral Mount Shasta volcano, California, and debris-avalanche hazard zonation. U.S. Geological Survey Bulletin 1861:32

Davidson J, Turner S, Handley H, Macpherson C, Dosseto A (2007) Amphibole "sponge" in arc crust? Geology 35: 787-790.

Dosseto A, Turner SP, Sandiford M, Davidson J (2008) Uranium-series isotope and thermal constraints on the rate and depth of silicic magma genesis. Geological Society of London, Special Publications 304: 169-181.

Ducea MN, Saleeby JB (1998) The age and origin of a thick mafic-ultramafic keel from beneath the Sierra Nevada batholith. Contributions to Mineralogy and Petrology 133: 169-185.

Elkins-Tanton LT, Grove TL, Donnelly-Nolan J (2001) Hot, shallow mantle melting under the Cascades volcanic arc. Geology 29: 631-634.

Garrison JM, Davidson JP (2003) Dubious case for slab melting in the Northern volcanic zone of the Andes. Geology 31: 565-568.

Grove TL, Baker MB, Price RC, Parman SW, Elkins-Tanton LT, Chatterjee N, Müntener O (2005) Magnesian andesite and dacite lavas from Mt. Shasta, northern California: products of fractional crystallization of $\mathrm{H}_{2} \mathrm{O}$-rich mantle melts. Contributions to Mineralogy and Petrology 148: $542-$ 565.

Grove TL, Elkins-Tanton LT, Parman SW, Chatterjee N, Müntener O, Gaetani GA (2003) Fractional crystallization and mantle-melting controls on calc-alkaline differentiation trends. Contributions to Mineralogy and Petrology 145: 515-533.

Grove TL, Parman SW, Bowring SA, Price RC, Baker MB (2002) The role of an $\mathrm{H}_{2} \mathrm{O}$-rich fluid component in the generation of primitive basaltic andesites and andesites from the Mt. Shasta region, $\mathrm{N}$ California. Contributions to Mineralogy and Petrology 142: 375-396.

Harry DL, Green NL (1999) Slab dehydration and basalt petrogenesis in subduction systems involving very young oceanic lithosphere. Chemical Geology 160: 309-333.

Hegner E, Tatsumoto M (1987) Pb, Sr, and Nd isotopes in basalts and sulfides from the Juan-de-Fuca Ridge. Journal of Geophysical Research-Solid Earth and Planets 92: 11380-11386. 
Hidalgo PJ, Rooney TO (2010) Crystal fractionation processes at Baru volcano from the deep to shallow crust. Geochemistry Geophysics Geosystems 11.

Hildreth W (2007) Quaternary magmatism in the Cascades-geologic perspectives. Unites States Geological Survey Professional Paper 1744: 125.

Hildreth W, Moorbath S (1988) Crustal contributions to arc magmatism in the Andes of central Chile. Contributions to Mineralogy and Petrology 98: 455-489.

Jicha BR, Johnson CM, Hildreth W, Beard BL, Hart GL, Shirey SB, Singer BS (2009) Discriminating assimilants and decoupling deep- vs. shallow-level crystal records at Mount Adams using ${ }^{238} \mathrm{U}$ ${ }^{230}$ Th disequilibria and Os isotopes. Earth and Planetary Science Letters 277: 38-49.

Jicha BR, Hart GL, Johnson CM, Hildreth W, Beard BL, Shirey SB, Valley JW (2009b) Isotopic and trace element constraints on the petrogenesis of lavas from the Mt. Adams volcanic field, Washington. Contributions to Mineralogy and Petrology 157: 189-207.

Le Voyer M, Rose-Koga EF, Shimizu N, Grove TL, Schiano P (2010) Two contrasting $\mathrm{H}_{2} \mathrm{O}$-rich components in primary melt inclusions from Mount Shasta. Journal of Petrology 51: 1571-1595.

Lee CTA, Cheng X, Horodyskyj U (2006) The development and refinement of continental arcs by primary basaltic magmatism, garnet pyroxenite accumulation, basaltic recharge and delamination: insights from the Sierra Nevada, California. Contributions to Mineralogy and Petrology 151: 222242.

Leeman WP, Smith DR, Hildreth W, Palacz Z, Rogers N (1990) Compositional diversity of late Cenozoic basalts in a transect across the southern Washington Cascades- implications for subduction zone magmatism. Journal of Geophysical Research- Solid Earth and Planets 95: 19561-19582.

Magna T, Wiechert U, Grove TL, Halliday AN (2006) Lithium isotope fractionation in the southern Cascadia subduction zone. Earth and Planetary Science Letters 250: 428-443.

Mercer CN, Johnston AD (2008) Experimental studies of the P-T- $\mathrm{H}_{2} \mathrm{O}$ near-liquidus phase relations of basaltic andesite from North Sister Volcano, High Oregon Cascades: Constraints on lower-crustal mineral assemblages. Contributions to Mineralogy and Petrology 155: 571-592.

Müntener O, Kelemen PB, Grove TL (2001) The role of $\mathrm{H}_{2} \mathrm{O}$ during crystallization of primitive arc magmas under uppermost mantle conditions and genesis of igneous pyroxenites: an experimental study. Contributions to Mineralogy and Petrology 141: 643-658.

Newman S, Macdougall JD, Finkel RC (1986) Petrogenesis and ${ }^{230} \mathrm{Th}^{238} \mathrm{U}$ disequilibrium at Mt. Shasta, California, and in the Cascades. Contributions to Mineralogy and Petrology 93: 195-206.

Ottonello G, Ernst WG, Joron JL (1984) Rare-earth and 3D transition element geochemistry of peridotitic rocks. 1. Peridotites from the western Alps. Journal of Petrology 25: 343-372.

Price RC, Turner S, Cook C, Hobden B, Smith IEM, Gamble JA, Handley H, Maas R, Möbis A (2010) Crustal and mantle influences and U-Th-Ra disequilibrium in andesitic lavas of Ngauruhoe volcano, New Zeland. Chemical Geology 277: 355-373.

Price RC, George R, Gamble JA, Turner S, Smith IEM, Cook C, Hobden B, Dosseto A (2007) U-Th-Ra fractionation during crustal-level andesite formation at Ruapehu volcano, New Zealand. Chemical Geology 244: 437-451.

Qian Q, Hermann J (2013) Partial melting of lower crust at 10-15 kbar: constraints on adakite and TTG formation. Contributions to Mineralogy and Petrology 165: 1195-1224.

Rapp RP, Watson EB (1995) Dehydration melting of metabasalt at 8-32 kbard- Implications for continental growth and crust-mantle recycling. Journal of Petrology 36: 891-931. 
Reagan MK, Sims KWW, Erich J, Thomas RB, Cheng H, Edwards RL, Layne G, Ball L (2003) Time-scales of differentiation from mafic parents to rhyolite in North American continental arcs. Journal of Petrology 44: 1703-1726.

Reubi O, Bourdon B, Dungan MA, Koornneef JM, Sellés D, Langmuir CH, Aciego S (2011) Assimilation of the plutonic roots of the Andean arc controls variations in $\mathrm{U}$-series disequilibria at Volcan Llaima, Chile. Earth and Planetary Sciences 303: 37-47.

Rose EF, Shimizu N, Layne GD, Grove TL (2001) Melt production beneath Mt. Shasta from boron data in primitive melt inclusions. Science 293: 281-283.

Rubatto D, Hermann J (2007) Experimental zircon/melt and zircon/garnet trace element partitioning and implications for the geochronology of crustal rocks. Chemical Geology 241: 38-61

Ruscitto DM, Wallace PJ, Johnson ER, Kent AJR, Bindeman IN (2011) Volatile contents of mafic magmas from cinder cones in the Central Oregon High Cascades: Implications for magma formation and mantle conditions in a hot arc. Earth and Planetary Science Letters 298: 153-161.

Schmidt ME, Grunder AL, Rowe MC (2008) Segmentation of the Cascade Arc as indicated by Sr and Nd isotopic variation among diverse primitive basalts. Earth and Planetary Science Letters 266: 166181.

Sen C, Dunn T (1994) Dehydration melting of a basaltic composition amphibolite at 1.5 and $2.0 \mathrm{GPa}$ : implications for the origin of adakites. Contributions to Mineralogy and Petrology 117: 345-364.

Stanley WD, Mooney WD, Fuis GS (1990) Deep crustal structure of the Cascade Range and surrounding regions from seismic refraction and magnetotelluric data. Journal of Geophysical Research-Solid Earth and Planets 95: 19419-19438.

Streck MJ, Leeman WP, Chesley J (2007) High-magnesian andesite from Mount Shasta: A product of magma mixing and contamination, not a primitive mantle melt. Geology 35: 351-354.

Trimble DA, Clynne MA, Robinson SW (1984) The application of uranium-thorium systematics to rocks from the Lassen dome field, California. U.S. Geological Survey Open File Report 84-371: 108.

Turner S, Bourdon B, Gill J (2003) Insights into magma genesis at convergent margins from U-series isotopes, in: Bourdon B, Henderson GM, Lundstrom CC, Turner SP (Eds.), Uranium-Series Geochemistry, pp. 255-315.

Turner S, Hawkesworth C, Rogers N, Bartlett J, Worthington T, Hergt J, Pearce J, Smith I (1997) ${ }^{238} \mathrm{U}_{-}{ }^{230} \mathrm{Th}$ disequilibria, magma petrogenesis, and flux rates beneath the depleted Tonga-Kermadec island arc. GeochImica et CosmochImica Acta 61: 4855-4884.

Volpe AM, Hammond PE (1991) ${ }^{238} \mathrm{U}^{230} \mathrm{Th}^{226}$ Ra disequilibriua in young Mt. St. Helens rocks: Time constraints for magma formation and crystallization. Earth and Planetary Science Letters 107: 475-486.

White WM, Hofmann AW, Puchelt $\mathrm{H}$ (1987) Isotope geochemistry of Pacific midocean ridge basalt. Journal of Geophysical Research-Solid Earth and Planets 92: 4881-4893.

Wilson DS (1988) Tectonic history of the Juan-De-Fuca ridge over the last 40 million years. Journal of Geophysical Research-Solid Earth and Planets 93: 11863-11876.

Wolf MB, Wyllie PJ (1993) Garnet growth during mphiboloite anatexis- Implications of a garnetiferous resitite. Journal of Geology 101: 357-373.

Wolf MB, Wyllie PJ (1994) Dehydration-melting of amphibolite at 10 kbar- The effects of temperature and time. Contributions to Mineralogy and Petrology 115: 369-383.

Yokoyama T, Kuritani T, Kobayashi K, Nakamura E (2006) Geochemical evolution of a shallow magma plumbing system during the last 500 years, Miyakejima volcano, Japan: constraints from ${ }^{238} \mathrm{U}$ ${ }^{230} \mathrm{Th}-{ }^{226}$ Ra systematics. Geochimica et Cosmochimica Acta 70: 2885-2901. 
Zeichert TA (2004) The evolution of magmas at a large stratocone volcano, Mount Shasta, N. California. Master Thesis, University of Wisconsin-Madison.

Zellmer G, Turner S, Hawkesworth C (2000) Timescales of destructive plate margin magmatism: new insights from Santorini Aegean volcanic arc. Earth and Planetary Science Letters 174: 265-281.

\section{Figure Captions}

Figure 1. Simplified geologic map of the Mount Shasta area, showing the four-cone building stages comprising the current edifice. Inset shows the Cascade arc.

Figure 2. Mt. Shasta and Cascade lavas plotted on a traditional U-Th equiline diagram. Mount Shasta data from Newman et al. (1986; diamonds) are plotted with data from Crater Lake (green field) and Mt. Adams (pink field) in (A). Data from this study (squares) are plotted with that of Newman et al. (1986; blue field) in (B). Average error for the Newman et al. (1986) and this study are shown in (A) and (B) respectively. Samples plotting to the left of the equiline have $\left({ }^{230} \mathrm{Th} /{ }^{238} \mathrm{U}\right)>1$ and are considered to be in ${ }^{230} \mathrm{Th}$-excess; those plotting to the right of the equiline have $\left({ }^{230} \mathrm{Th} /{ }^{238} \mathrm{U}\right)<1$ and are in ${ }^{238} \mathrm{U}$-excess. Cascade lavas are dominated by ${ }^{230} \mathrm{Th}$-excess. Rock type abbreviations are as follows: basaltic andesite (BA), andesite (A), dacite (D). See Appendix $C$ for complete list of data sources.

Figure $3 .{ }^{87} \mathrm{Sr} /{ }^{86} \mathrm{Sr}$ relative to $\mathrm{SiO}_{2}$ for Mt. Shasta and Cascades lavas, including Crater Lake (green field), Mt. Adams (pink field), and Mt. Lassen (light grey field). Data from the Juan de Fuca and Gorda MORB are shown as a dark gray field. Mount Shasta data from previous studies are outlined with a dotted line in (B). "Regional lavas" refer to primitive lavas erupted from flank vents and nearby cones. Mount Shasta data from Grove et al. (2002) (circles); Zeichert (2004) (triangles); this study (squares). All errors are smaller than the data symbols. Refer to Appendix $\mathrm{C}$ for a complete list of data sources.

Figure 4. Equiline diagram with fractional crystallization models illustrating the effects of zircon and apatite crystallization on ${ }^{230} \mathrm{Th}-{ }^{238} \mathrm{U}$ compositions. Small degrees of zircon crystallization can create large ${ }^{230}$ Th-excesses (up to $28.5 \%$ at $0.3 \%$ crystallization) but higher degrees of apatite crystallization are required to generate even moderate ${ }^{238} \mathrm{U}$-excesses (up to $10.2 \%{ }^{238} \mathrm{U}$-excess at $10 \%$ crystallization). Subtraction of this extent of zircon and apatite, however, requires parental magmas with $1609 \mathrm{ppm} \mathrm{Zr}$ and 3.0 wt. $\% \mathrm{P}_{2} \mathrm{O}_{5}$ in order to produce lavas with $116 \mathrm{ppm} \mathrm{Zr}$ and 0.24 wt. $\% \mathrm{P}_{2} \mathrm{O}_{5}$, the average of that measured in Mt. Shasta andesites. Individual fractional crystallization models for zircon and apatite are based on Rayleigh fractional crystallization. Initial $U$ and Th contents for fractional crystallization models are based on the average composition of basaltic andesite at Mt. Shasta and are estimated to be 0.77 and $1.94 \mathrm{ppm}$, respectively. Refer to section 4.1.1 for $U$ and Th partition coefficients in zircon and apatite. We note that the amount of ${ }^{230} \mathrm{Th}$ - and ${ }^{238} \mathrm{U}$-excess created at a given percent zircon or apatite crystallization is dependent on the choice of $U$ and Th partition coefficients, although reasonable amounts of crystallization are only achieved at very high $U$ and Th partition coefficients, respectively . See Appendix D.1 for a more complete discussion of model parameters. 
Figure 5. $U$ and Th contents demonstrate that Mt. Shasta lavas are depleted in Th relative to $U$ (inset), even in the Shastina unit where $\mathrm{Zr}$ depletion with increasing $\mathrm{SiO}_{2}$ suggests possible zircon crystallization. Solid black and grey trendlines represent quantitative linear regressions of the Shastina and Mt. Shasta data respectively. Dotted lines illustrate the effects of variable proportions of zircon and apatite crystallization from a parental magma on $U$ and Th contents: $0.3 \%$ zircon and $0 \%$ apatite crystallization (blue), $0.3 \%$ zircon and $15 \%$ apatite crystallization (green), and $0.3 \%$ zircon and $25 \%$ apatite crystallization (yellow). Fractional crystallization models are based on Rayleigh fractional crystallization, and, given similarly low partition coefficients for $U$ and Th in major phases, crystallization models are simplified to assume that all $U$ and Th is partitioned into zircon and apatite. Distribution coefficients and starting compositions are as in Figure 4 . The amount of apatite crystallization required to reproduce $\mathrm{Th} / \mathrm{U}$ trends of the Mt. Shasta lavas at $0.3 \%$ zircon crystallization is dependent on the $\mathrm{Th} / \mathrm{U}$ ratio of the starting composition and the partition coefficients of $U$ and Th in zircon and apatite. Reasonable amounts of apatite crystallization, however, are only achieved in magmas with very high initial Th/U ratios or by selecting unusually high partition coefficients for Th and $U$ in apatite. Refer to Appendix D.2 for a more complete discussion of model parameters. Mount Shasta data from Grove et al. (2002) (circles); Zeichert (2004) (triangles); this study (squares).

Figure 6. Equiline diagram with non-modal batch melting models for a mafic amphibolite lower crust and a spinel lherzolite mantle. Partial melts of both components are able to generate ${ }^{230} \mathrm{Th}$-excess. Melting models and estimated positions of mantle and crustal components are based on Ankney et al. (2013). Initial $U$ and Th contents of the mantle and lower crustal are estimated to be 0.05 and 0.145 ppm and 1 and $2.33 \mathrm{ppm}$, respectively. Both the mantle and lower crust are assumed to be older than $300 \mathrm{kyr}$ and therefore lie on the equiline. The lower crustal component is constrained by Crater Lake data which converge on $\left({ }^{238} \mathrm{U} /{ }^{232} \mathrm{Th}\right.$ ) $=1.30$ (Ankney et al., 2013) and is taken to be the composition of the bulk crust. U-series data from Mt. Adams basalts (Jicha et al., 2009) constrain the position of the mantle component at $\left({ }^{238} \mathrm{U} /{ }^{232} \mathrm{Th}\right)=\left({ }^{230} \mathrm{Th} /{ }^{232} \mathrm{Th}\right)_{0}=1.05$. Solid lines denote the $\mathrm{U}$-Th isotope composition of mantle and lower crustal melts at melt fractions ( $X_{\text {mantle }}^{\text {melt }}$ and $X_{\text {lower crust }}^{\text {melt }}$, respectively) ranging from 0.01 to 0.2 . The dashed line shows mixing between mantle and lower crustal melts at $X_{\text {mantle }}^{\text {melt }}=X_{\text {lower crust }}^{\text {melt }}=0.15$. Provided that garnet is the only phase in our model capable of generating significant ${ }^{230} \mathrm{Th}$-excesses $(>10 \%)$ at moderate to high melt fractions $\left(0.05<X^{\text {melt }} \geq 0.20\right)$, the extent of ${ }^{230} \mathrm{Th}$-excess produced during melting is largely dependent on the choice of partition coefficient for $U$ and Th in garnet. Refer to Appendix D.3 for a more complete discussion of model parameters. Diamond symbols denote lavas with significant ${ }^{230}$ Th-excess, while samples on/near the equiline are shown as squares. The red shaded field represents the ${ }^{238} \mathrm{U}-{ }^{230} \mathrm{Th}$ composition of melts dominated by interaction with garnet-bearing lower crustal rocks; blue shading shows the ${ }^{238} \mathrm{U}-{ }^{230}$ Th composition of melts dominated by interaction with non-garnet-bearing bulk crust.

Figure 7. Variation of $\left({ }^{230} \mathrm{Th} /{ }^{238} \mathrm{U}\right)_{0}$ with respect to $\mathrm{Ce} / \mathrm{Y}$. A modeled mixture of $15 \%$ mantle and $15 \%$ lower crustal melts (solid black line; dashed line in Figure 6) predicts high ${ }^{230} \mathrm{Th}$-excess at high $\mathrm{Ce} / \mathrm{Y}$ as a function of garnet production during dehydration melting of the lower crust. A combination of crustal residence times and assimilation of non-garnet-bearing bulk crust may explain the deviation of the Mt. Shasta samples from the modeled mixture (dashed lines). Residence times of $25 \mathrm{kyr}(\mathrm{A})$ and $50 \mathrm{kyr}$ (B) are shown to illustrate how variable residence time affects the amount of bulk crustal assimilation (from 
20-80\% bulk crustal assimilation or B.C.A.) required to reproduce the $\left({ }^{230} \mathrm{Th} /{ }^{238} \mathrm{U}\right)_{0}$ of the lavas at a given $\mathrm{Ce} / \mathrm{Y}$ ratio. Notably, one regional lava (09SH1286) has a higher $\left({ }^{230} \mathrm{Th} /{ }^{238} \mathrm{U}\right)_{0}$ than predicted by the modeled mixture. We attribute this, in part, to poor age constraints effecting the eruptive age correction on the $\left({ }^{230} \mathrm{Th} /{ }^{238} \mathrm{U}\right)_{0}$ ratio (Table A.1). Initial $\mathrm{U}$ and Th contents and isotopic compositions of the mantle and lower crustal end members are as in Figure 6; initial $\mathrm{Ce}$ and $\mathrm{Y}$ contents are estimated to be 1.785 and 4.37 and 16 ppm, respectively. A bulk crust with a starting composition of 43 ppm Ce, 19 ppm Y, $1 \mathrm{ppm} \mathrm{U,} 2.3 \mathrm{ppm}$ Th, and a $\left({ }^{230} \mathrm{Th} /{ }^{238} \mathrm{U}\right)$ ratio of 1 was selected for the assimilant. We note that increasing the $\mathrm{Ce} / \mathrm{Y}$ ratio of the bulk crust decrease predictions of bulk crustal assimilation for the same length of magma storage (25-50 kyr), such that the extent of assimilation cannot be robustly quantified without independent constraints. See appendix D.4 for a more complete discussion of model parameters. Diamond symbols denote lavas with significant ${ }^{230} \mathrm{Th}$-excess, while samples on/near the equiline are shown as squares. The red shaded field represents the ${ }^{238} \mathrm{U}-{ }^{230} \mathrm{Th}$ of melts dominated by interaction with garnet-bearing lower crustal rocks; blue shading shows the ${ }^{238} \mathrm{U}-{ }^{230} \mathrm{Th}$ composition of melts dominated by interaction with non-garnet bearing bulk crust.

Figure 8. $\left({ }^{230} \mathrm{Th} /{ }^{232} \mathrm{Th}\right)_{0}(\mathrm{~A}, \mathrm{C})$ and ${ }^{230} \mathrm{Th}$-excess (B, D) vs. ${ }^{87} \mathrm{Sr} /{ }^{86} \mathrm{Sr}$ at Mt. Shasta. Relatively uniform $\left({ }^{230} \mathrm{Th} /{ }^{232} \mathrm{Th}\right)_{0}$ ratios in individual cone-building stages reflect distinct mixing proportions of mantle and lower crustal melts $\left(M_{m: l c}\right)$, therefore $\mathrm{Sr}$ isotope variability within eruptive groups cannot be attributed to fundamental differences in mantle and lower crustal components. Similarly, the same range of ${ }^{87} \mathrm{Sr} /{ }^{86} \mathrm{Sr}$ is observed in samples with and without ${ }^{230} \mathrm{Th}$-excess, such that the total amount of non-garnetbearing crustal assimilation (which decreases $\left({ }^{230} \mathrm{Th} /{ }^{238} \mathrm{U}\right)_{0}$ within eruptive units) cannot be solely responsible for producing variable $\mathrm{Sr}$ isotope compositions. Instead, $\mathrm{Sr}$ isotope variability may be a function of a mixture of $15 \%$ mantle and $15 \%$ lower crustal melts (solid line) ascending through and assimilating portions of an old (> $300 \mathrm{kyr}$ ) crustal column that is heterogeneous with respect to $\mathrm{Sr}$ isotopes. Bulk crustal assimilation ("BCA"; 20-80\%; colored dashed lines) is modeled for two crustal end members that have the same $\left({ }^{230} \mathrm{Th} /{ }^{232} \mathrm{Th}\right)$ and $\left({ }^{238} \mathrm{U} /{ }^{232} \mathrm{Th}\right)$ but different ${ }^{87} \mathrm{Sr} /{ }^{86} \mathrm{Sr}$ ratios: $\mathrm{BCA} 1{ }^{87} \mathrm{Sr} /{ }^{86} \mathrm{Sr}=$ 0.7035 (dotted blue lines, based on Klamath Mountain plutons; Barnes et al., 1992) and BCA $2{ }^{87} \mathrm{Sr} /{ }^{86} \mathrm{Sr}=$ 0.7065 (dotted red lines, estimated from the Trinity Ophiolite; Brouxel and Lapierre, 1988). Residence times of $25 \mathrm{kyr}(\mathrm{A}, \mathrm{B})$ and $50 \mathrm{kyr}(\mathrm{C}, \mathrm{D})$ are shown to illustrate how variable residence time affects the amount of assimilation required. Initial $U$ and Th contents and isotopic compositions of the mantle and lower crustal end members are as in Figure 6; Initial Sr contents and isotopic compositions are estimated to be 20.3 ppm and 0.7025 and 925 ppm and 0.7028, respectively. Initial $U$ and Th contents of the bulk crustal assimilant are as in Figure 7; initial Sr contents are estimated to be 320 ppm for both BCA 1 and 2. See Appendix D.5 for a more complete discussion of model parameters. Diamond symbols denote lavas with significant ${ }^{230}$ Th-excesses, while samples on/near the equiline are shown as squares. The red shaded field represents the ${ }^{238} \mathrm{U}-{ }^{230} \mathrm{Th}$ of melts dominated by interaction with garnet-bearing lower crustal rocks; blue shading shows the ${ }^{238} \mathrm{U}-{ }^{230} \mathrm{Th}$ composition of melts dominated by interaction with non-garnet bearing bulk crust.

Figure 9. Simplified geologic map of Mt. Shasta with lava and pyroclastic flow deposits. . Symbol colors show $\mathrm{Sr}$ isotope compositions of vents: Blue $\left({ }^{87} \mathrm{Sr} /{ }^{86} \mathrm{Sr}=0.7028-0.7033\right)$, red $\left({ }^{87} \mathrm{Sr} /{ }^{86} \mathrm{Sr}=0.7034-0.7043\right)$; mixed colors signify vents where at least one outlier was erupted. Symbol shapes indicate age of erupted lavas: West Haight Mountain (10 point star), regional basalts (six point star), Goosenest 
(hexagon), Sand Flat (four point star), Sargents Ridge (circle), Misery Hill (diamond), Shastina (triangle), Hotlum (square). Data from Grove et al. (2002), Zeichert (2004), and this study.

Figure 10. Simplified illustration (not to scale) of expected magma generation and evolution processes at Mt. Shasta. (1) Partial melts of spinel Iherzolite mantle stalled and accumulated at the base of the lower crust to create a lower crustal hot zone (e.g. Annen et al., 2006) and promote (2) dehydration melting and garnet production in an amphibolite lower crust. Hydrous lower crustal melts subsequently mixed with primitive mantle-derived melts to impart ${ }^{230} \mathrm{Th}$-excesses and distinct $\left({ }^{230} \mathrm{Th} /{ }^{232} \mathrm{Th}\right)_{0}$ ratios on magmas. The magmatic products of this mixing event may have been stored in the lower crust for as long as $10^{5}$ years (e.g. Annen et al., 2006), during which time fractional crystallization and assimilation of deep non-garnet-bearing crust may also have occurred. (3) Buoyant mafic melts then ascended a midto-upper crustal column that was heterogeneous with respect to $\mathrm{Sr}$ isotopes (indicated by gradient; $\tan$ shading denotes crust with less radiogenic compositions (e.g. BCA $1 ;{ }^{87} \mathrm{Sr} /{ }^{86} \mathrm{Sr}=0.7035$ ), and light grey shading indicates more crust with more radiogenic compositions (e.g. BCA $2{ }^{87} \mathrm{Sr} /{ }^{86} \mathrm{Sr}=0.7065$ ). Fractional crystallization, magma mixing, and crustal assimilation occur over a range of depths to produce stratocone andesites and dacites that had variable ${ }^{87} \mathrm{Sr} /{ }^{86} \mathrm{Sr}$ and $\left({ }^{230} \mathrm{Th} /{ }^{238} \mathrm{U}\right)_{0}$ compositions. 


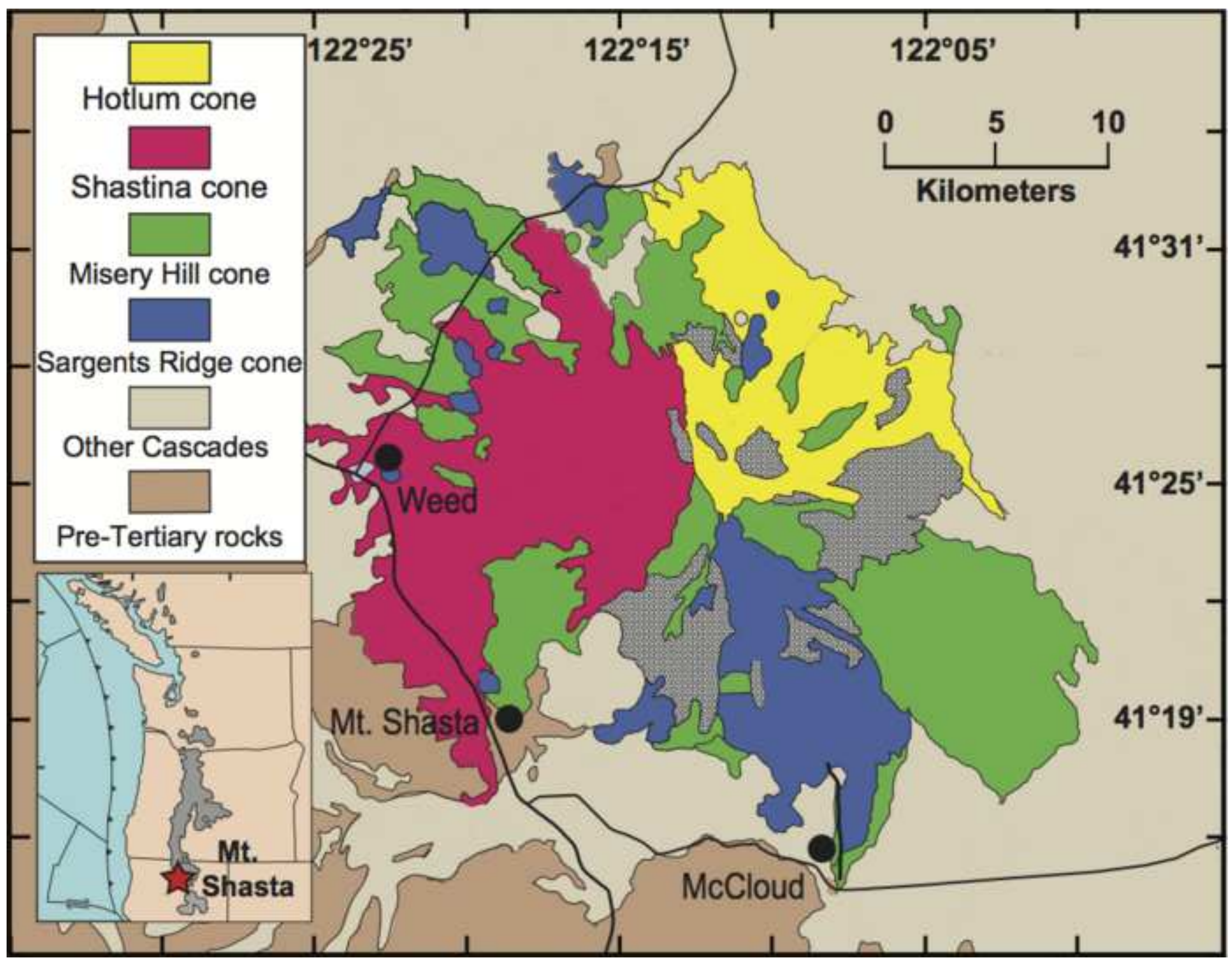




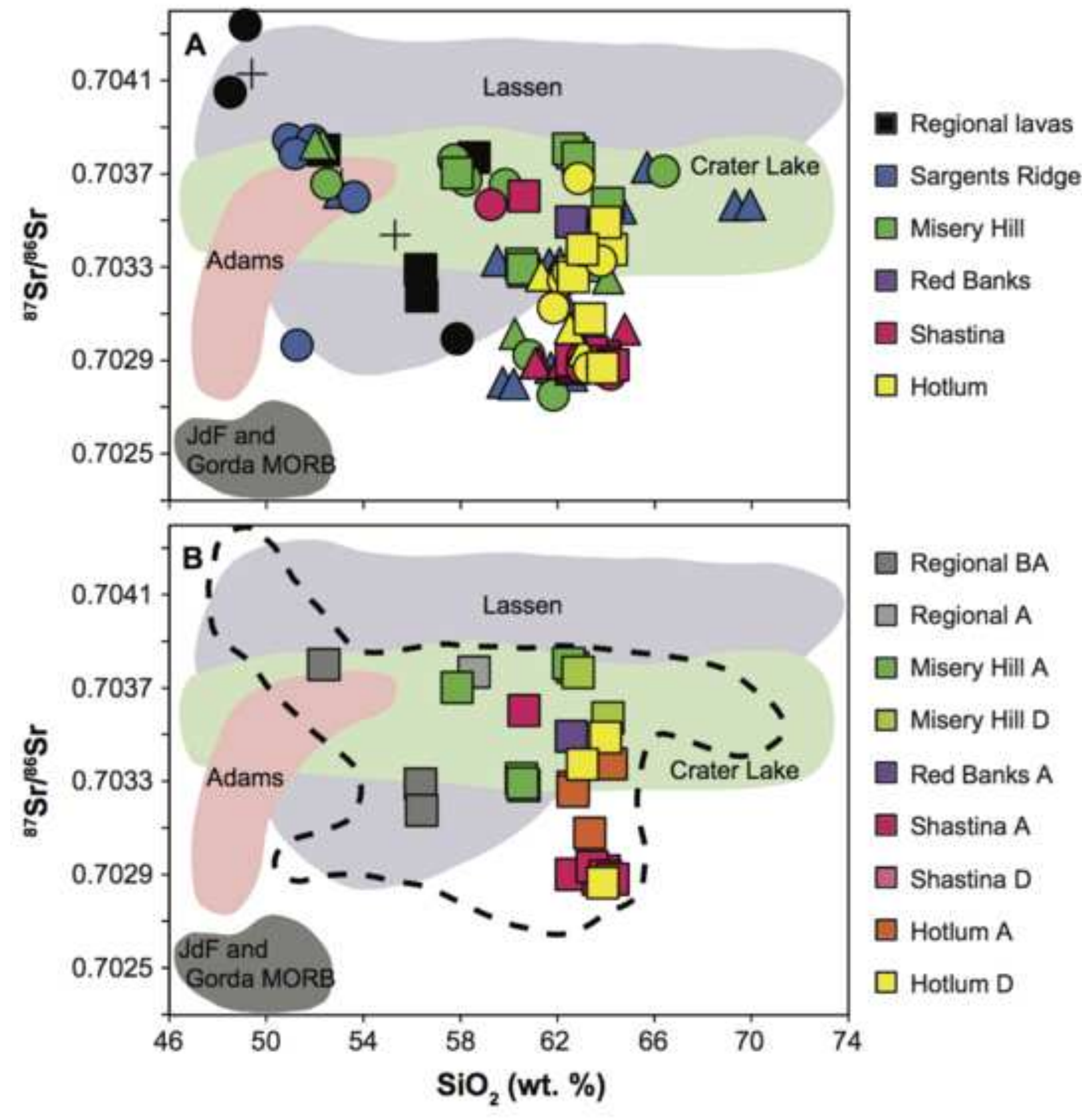

Figure 3 


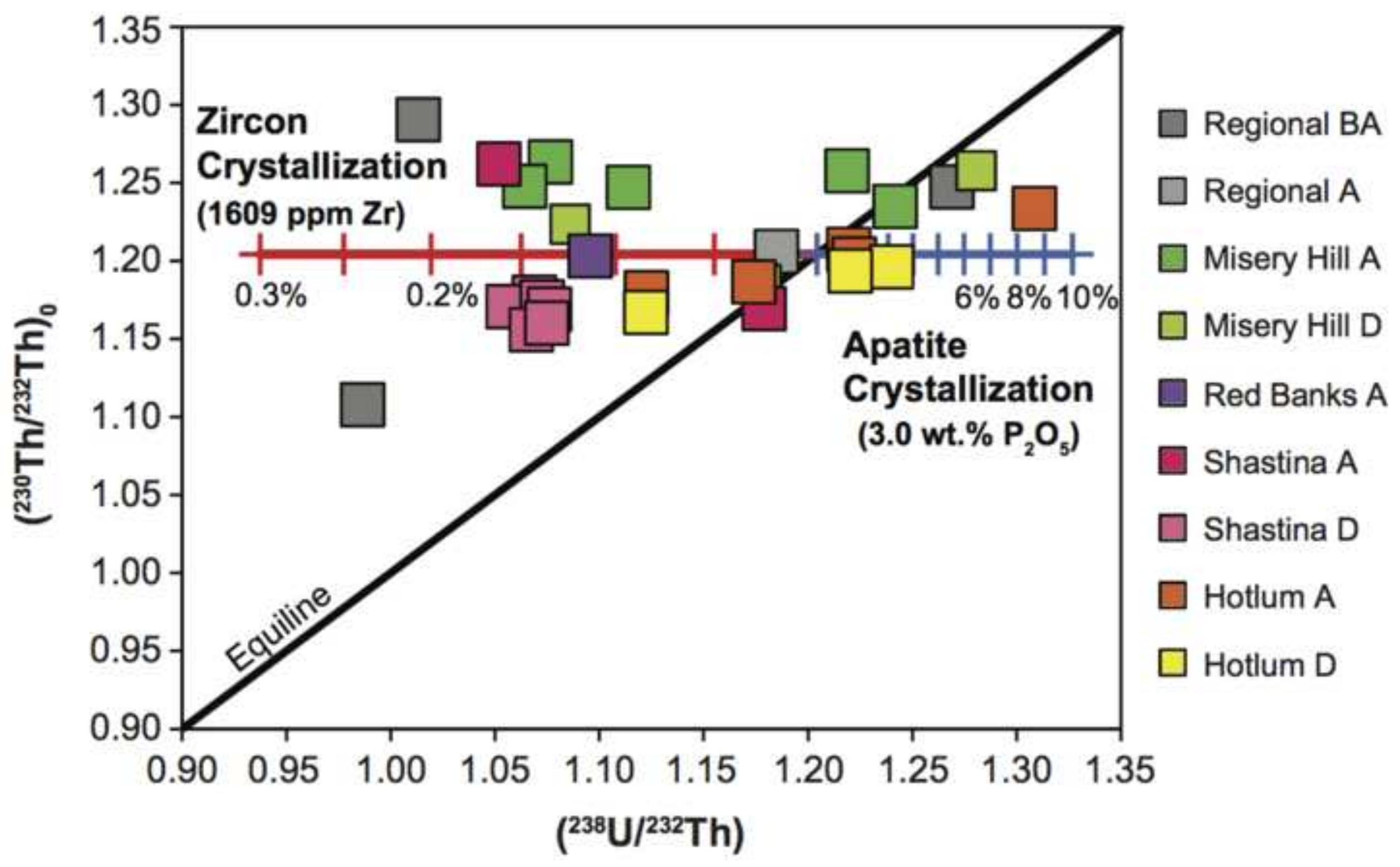




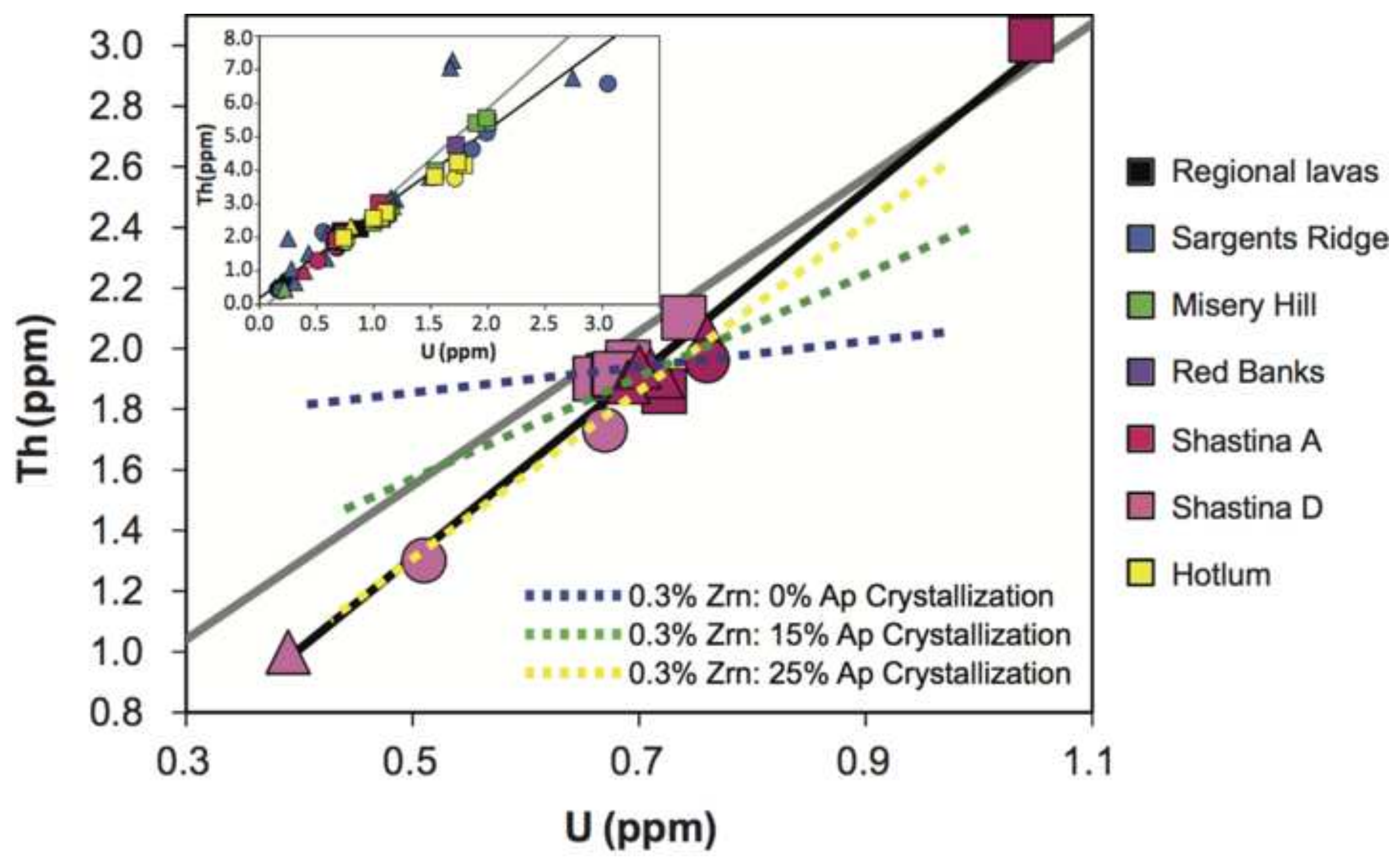




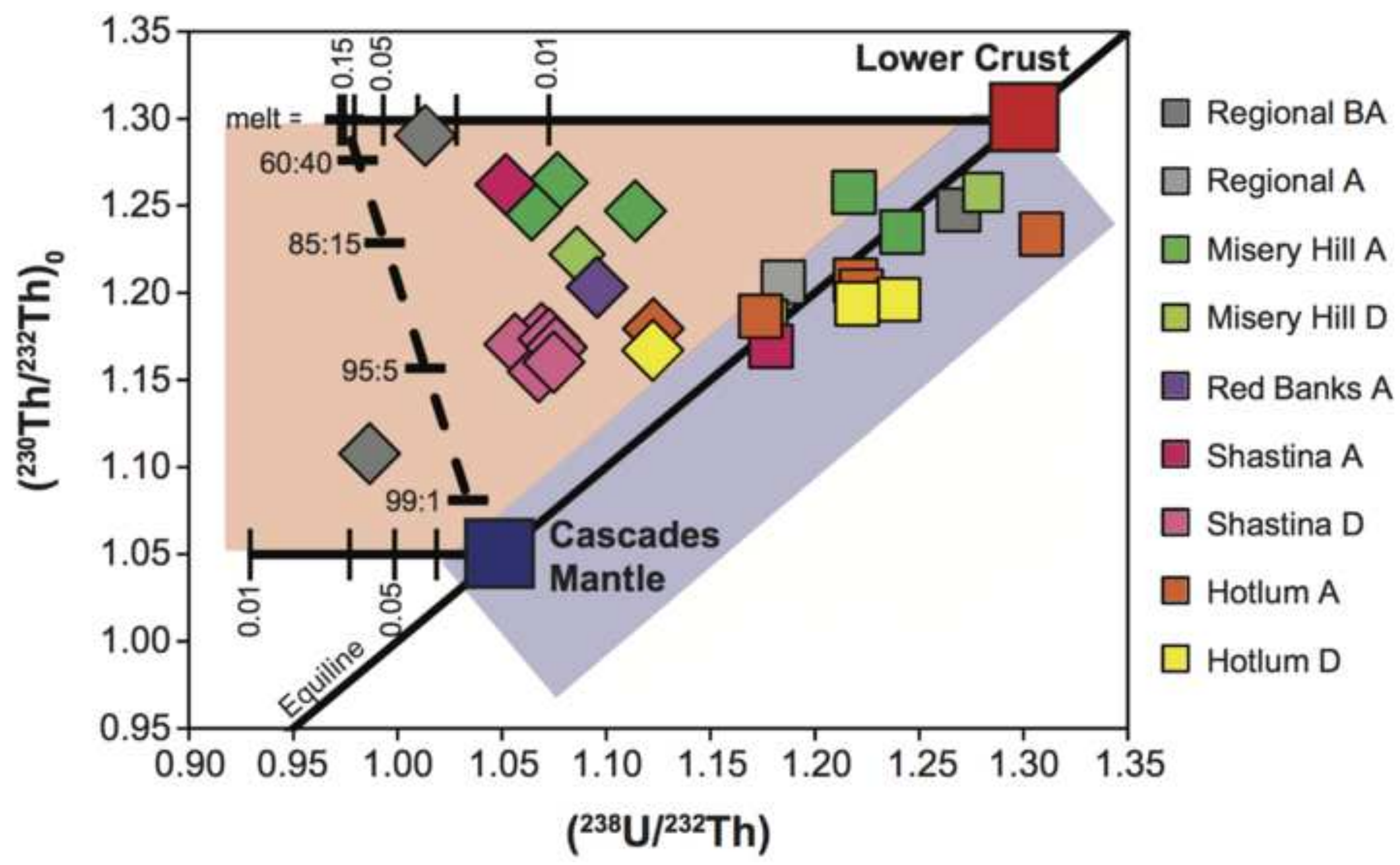



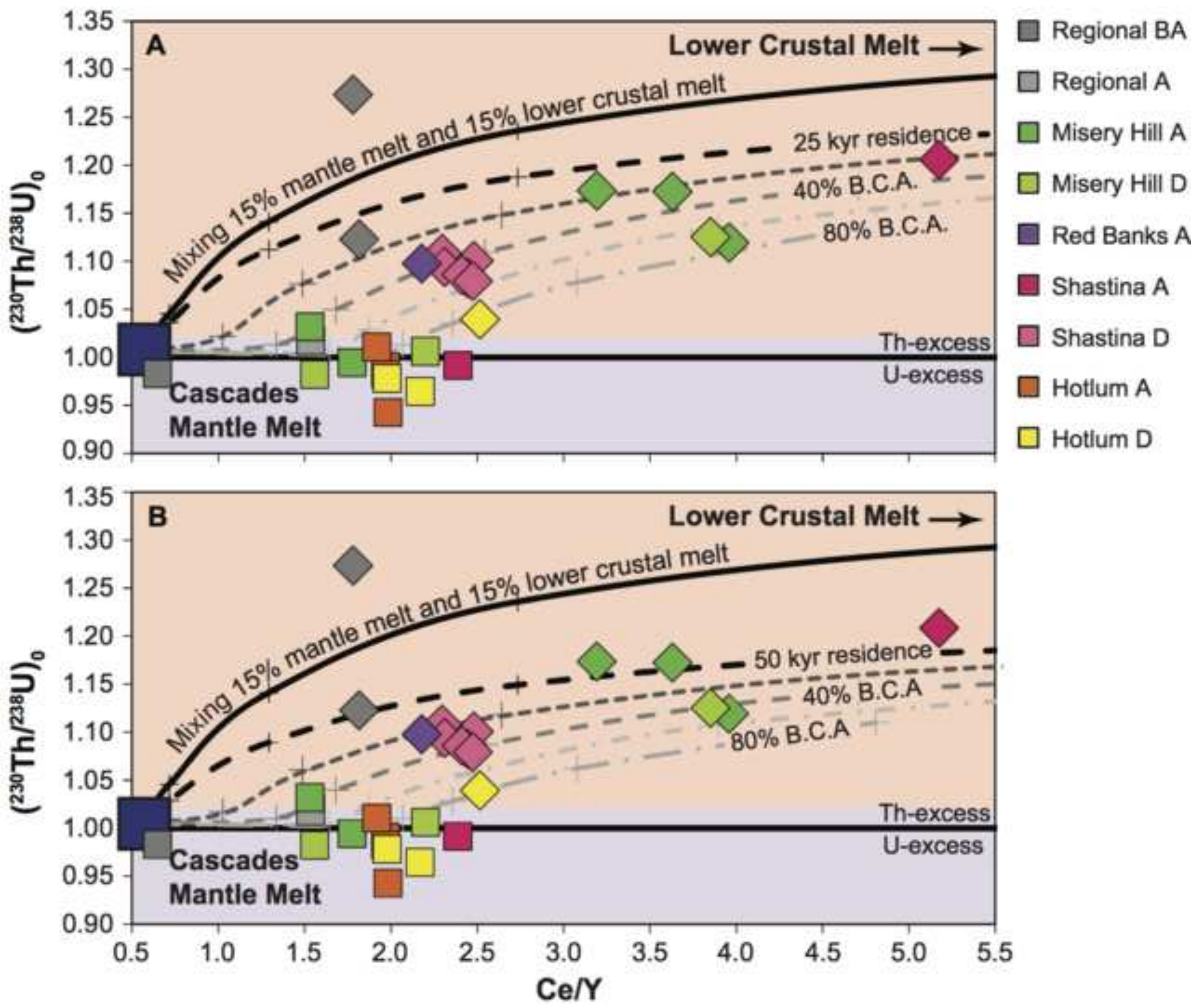

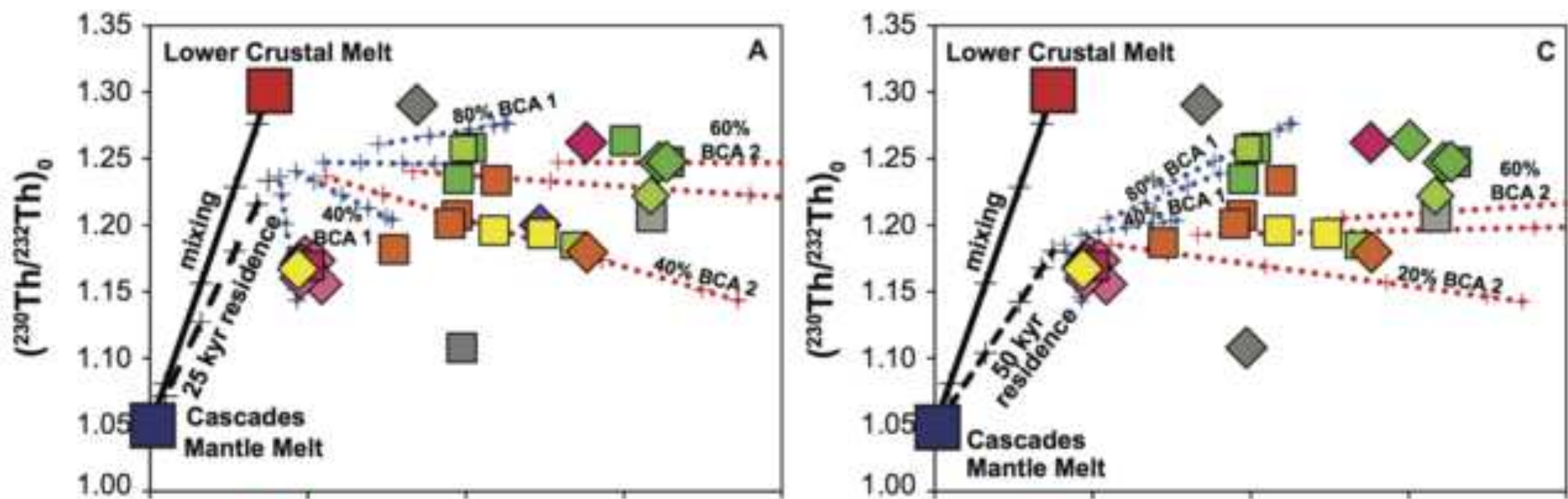

口 Regional BA

$\square$ Regional A

口 Misery Hill A

$\square$ Misery Hill D

口 Red Banks A

E Shastina A

$\square$ Shastina D

口 Hottum A

$\square$ Hotlum D
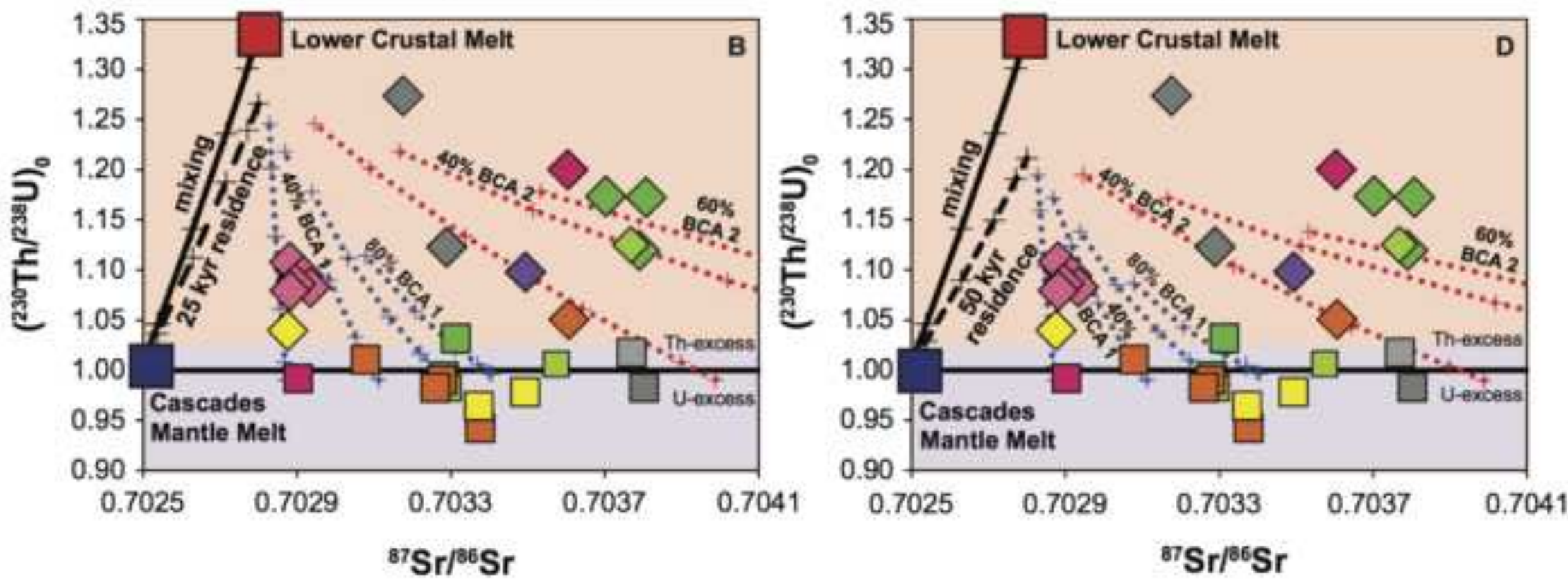


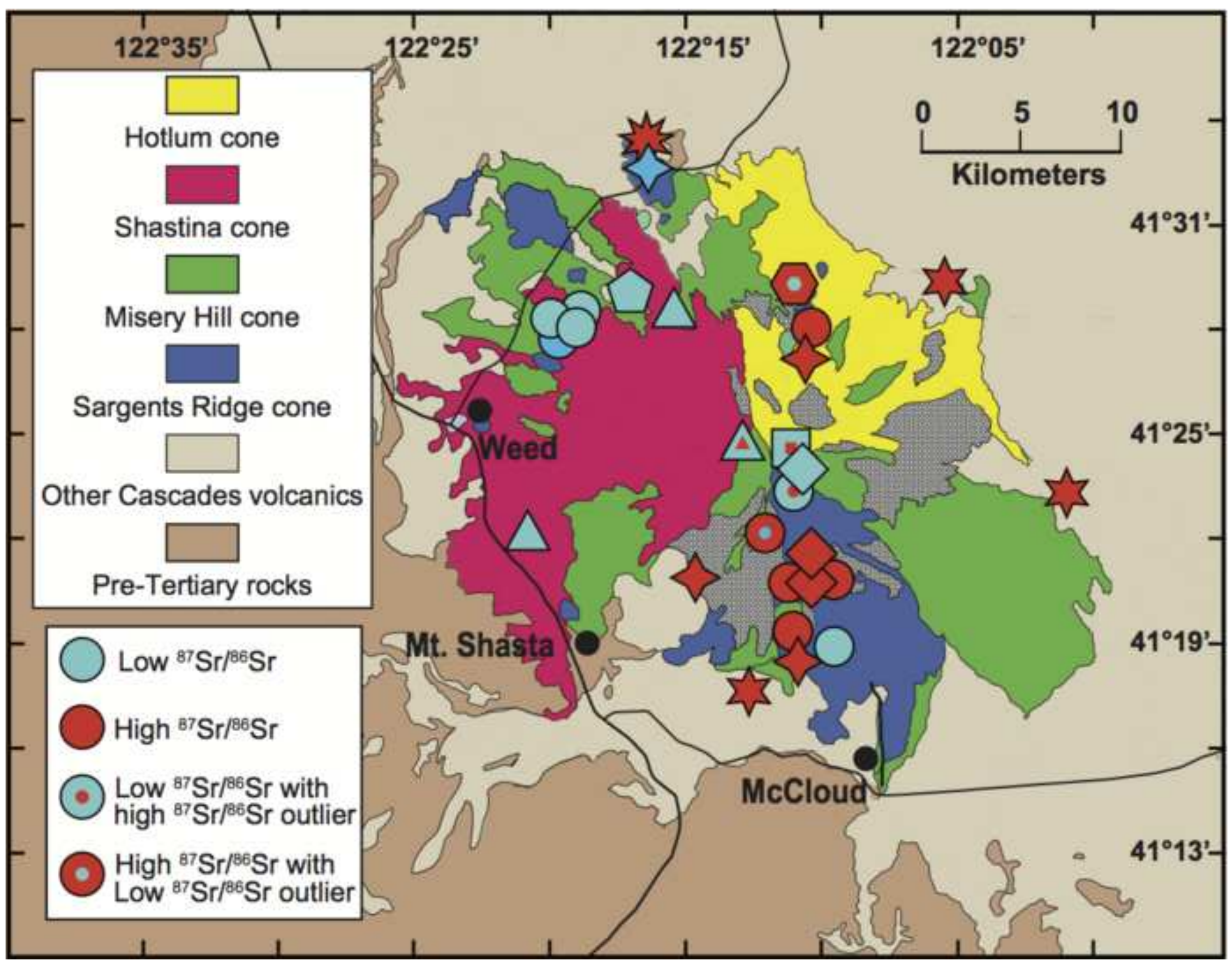


Hotlum

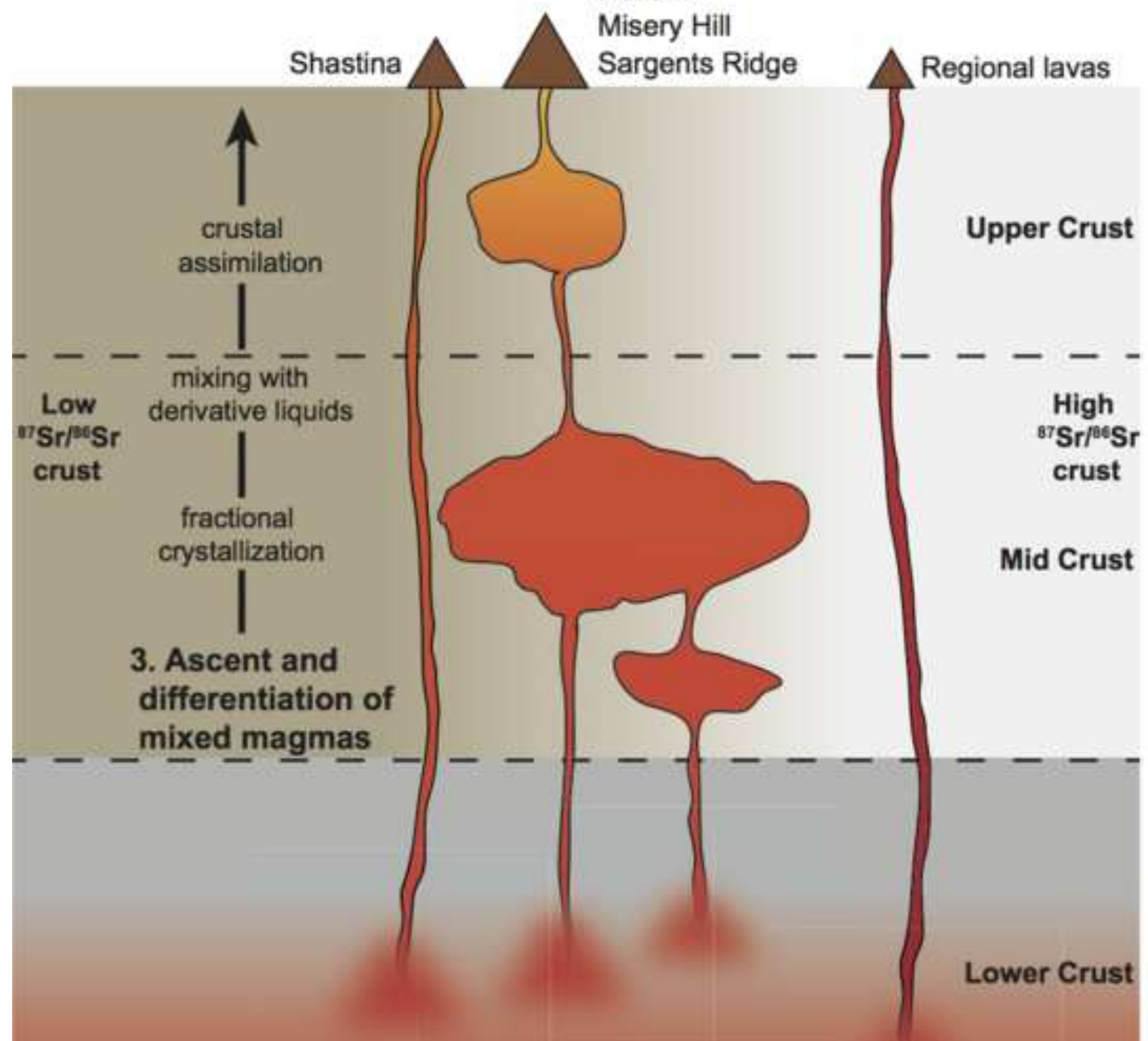

2. Dehydration melting, assimilation and storage
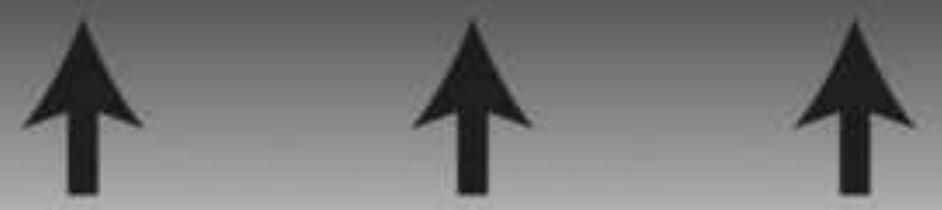

Upper Mantle

1. partial melts of mantle wedge 